\title{
Upper Ordovician brachiopods from the Montagne Noire (France): endemic Gondwanan predecessors of Prehirnantian low-latitude immigrants
}

\author{
JORGE COLMENAR, ENRIQUE VILLAS \& DANIEL VIZCAÏNO
}

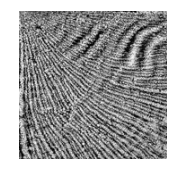

\begin{abstract}
The stratigraphy, brachiopod systematics and palaeoecology of the Upper Ordovician succession from the Cabrières Klippes, at the eastern ending of the southern slope of the Montagne Noire (southern France) are studied. Two new formations have been formally introduced: the Glauzy Formation (middle Katian, Ka2, in its uppermost fossiliferous strata) and the Gabian Formation (middle-upper Katian, Ka2-Ka4), to characterize, respectively, the thickly bedded quartzitic sandstones overlying volcaniclastic rocks, and the conformably overlying marls and limestones, rich in bryozoans, echinoderms and brachiopods. The systematic palaeontology of the brachiopods yielded in the uppermost beds of the Glauzy Formation has been studied, and five taxa are described, including a new platyorthid genus and species, Proclinorthis vailhanensis. The palaeoecological analysis of the Glauzy Fm., using both taphonomical and functional-morphological criteria, has allowed for the introduction of a new formal palaeoecological unit, the Svobodaina havliceki Community. It characterizes the recurrent low-diversity brachiopod association, usually dominated by S. havliceki, frequent in quartzitic sandstone lithofacies of the Upper Ordovician outcrops throughout southwestern Europe. It is interpreted as having developed in the shore face environments of the Benthic Assemblage 3 (BA-3), along the Gondwanan Mediterranean margin during the early- and mid-Katian. This new community is bounded coastward by an undescribed rhynchonellid community (BA-2) and seaward by the Nicolella Community (also BA-3), during its latest time span. This study allows a better understanding of when, why and how occurred the replacement of Gondwanan endemic associations, represented by the $S$. havliceki Community, by immigrant associations from low-latitude platforms, represented by the Nicolella Community, coinciding with the global warming Boda event. • Key words: brachiopods, lithostratigraphy, palaeoecology, Katian, Montagne Noire, Mediterranean margin, Gondwana.
\end{abstract}

COLMENAR, J., ViLlaS, E. \& ViZCAÏNO, D. 2013. Upper Ordovician brachiopods from the Montagne Noire (France): endemic Gondwanan predecessors of Prehirnantian low-latitude immigrants. Bulletin of Geosciences 88(1), 153-174 (8 figures). Czech Geological Survey, Prague. ISSN 1214-1119. Manuscript received March 3, 2012; accepted in revised form June 1, 2012; published online November 23, 2012; issued December 6, 2012.

Jorge Colmenar (corresponding author), Área de Paleontología, Dpto. CC. de la Tierra, Universidad de Zaragoza, Pedro Cerbuna 12,E-50009 Zaragoza (Spain); colmenar@unizar.es・Enrique Villas, Área de Paleontología, Dpto. CC. de la Tierra, Universidad de Zaragoza, Pedro Cerbuna 12, E-50009 Zaragoza (Spain); villas@ unizar.es •Daniel Vizcaïno, 7 rue Jean-Baptiste Chardin, Maquens, F-11090 Carcassonne (France); daniel.vizcaino@wanadoo.fr

The development of the brachiopod Nicolella Community during the upper Katian, coinciding with the global warming Boda event is typical of the South European margin of Gondwana. The community was introduced by Pickerill \& Brenchley (1979) in their study of the upper Sandbian-lower Katian strata of north Wales, to characterize a recurrent association of brachiopods adapted to silty calcareous and fine sands substrates located at mid-depth platform environments. At that time, its characteristic brachiopod constituents were widely spread throughout the low latitude continents. They did not arrive at the temperate to high latitude coasts of Gondwana until the late Katian, coinciding with the global warming Boda event (Fortey \& Cocks 2005). The simultaneous eustatic sea level rise and the global palaeogeographic configuration made the arrival of subequatorial currents to the region possible, carrying the larvae of different invertebrates previously unknown down there (Villas et al. 2002, Boucot et al. 2003, Jiménez-Sánchez \& Villas 2010).

The first adscription to the Nicolella Community of the Late Ordovician brachiopod fauna from southwestern Europe was made by Havlíček (1981), studying collections from the Cabrières Klippes, at the eastern end of the southern slope of the Montagne Noire, in southern France. This 


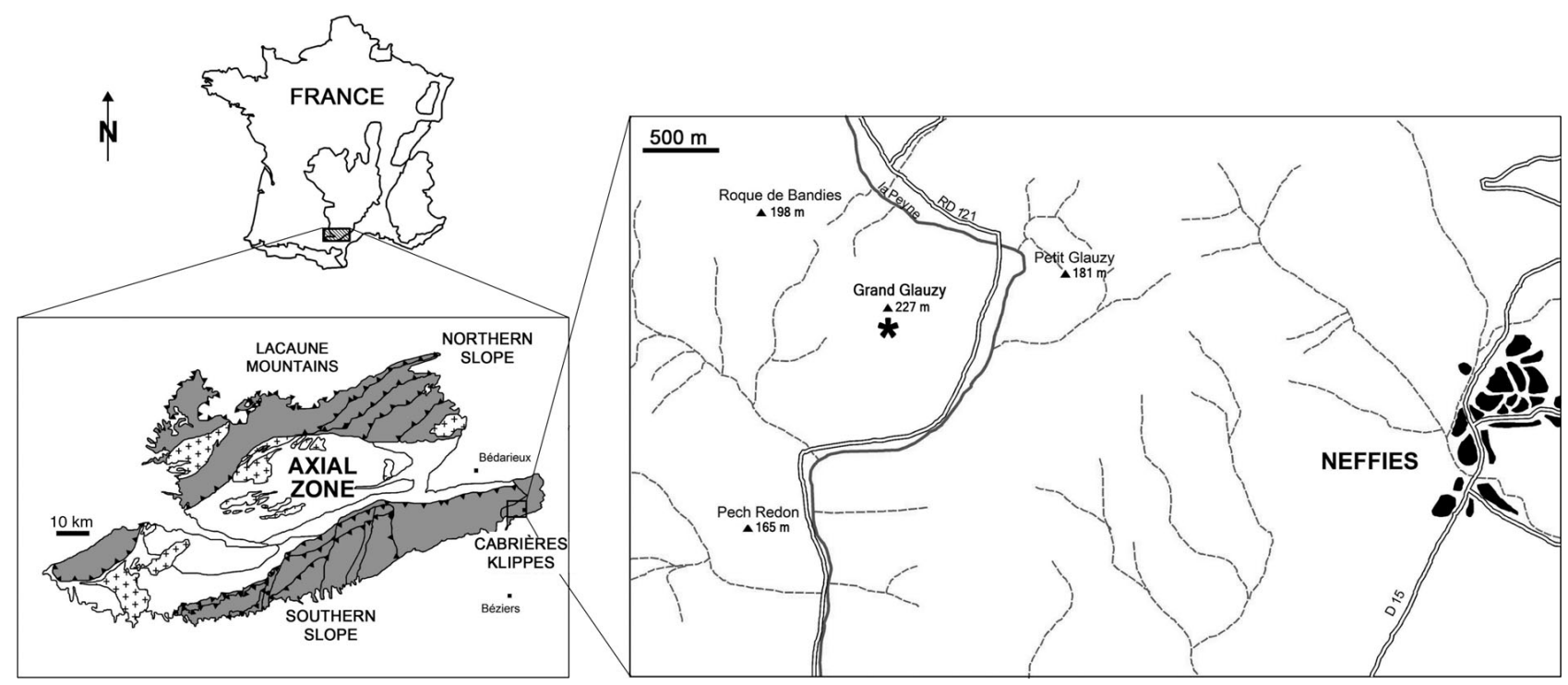

Figure 1. Geographical and geological setting. * - studied locality.

is the only region of the Montagne Noire where the Upper Ordovician crops out. However, Cambrian or Lower Ordovician rocks are well known from many other places of this southern prolongation of the French "Massif Central", especially from its southern slope (Álvaro \& Vizcaino 2001). In the Cabrières Klippes Upper Ordovician fossiliferous horizons are also known from the quartzitic sandstones underlying the carbonate rocks with the Nicolella Community. They have been known since the work of Graff (1874), Koenen (1886), Frech (1887), de Rouville (1888), Bergeron $(1889,1890)$ and de Rouville \& Delage (1892). These works were revised by Dreyfuss (1948), who named the rocks bearing the fossils as the "formation gréseuse" and described the brachiopods Rhynchotreta? nov. sp., Camarotoechia aff. llandoveriana var. diversiplicata Reed, 1917, Orthis (Rhipidomella) alternata Sowerby, 1839, Orthis? sp., Rafinesquina grandis (Sowerby, 1839), R. (Playfairia) aff. imbrex var. semiglobosa (Davidson, 1870), R. (Playfairia) imbrex var. nov., R. (Playfairia) aff. semiglobosina (Davidson, 1870), R. (Playfairia) deltoidea (Conrad, 1839), Leptaena rhomboidalis (Wilkens, 1769), Plectambonites (Sowerbyella) sericea (Dalman, 1828) var. ?, Stropheodonta corrugatella (Davidson, 1871) var., Strophomena sp., Orthis (Dalmanella?) exornata Sharpe, 1853 and $O$. (Rhipidomella) aff. inclyta Barrande, 1879. In addition to these brachiopods, Dreyfuss (1948) described the trilobites Dalmania exophthalma sp. nov. (= Dreyfussina exophthalma), Dalmania socialis var. proaeva Emmrich, 1839 (= Dalmanitina proaeva), Calymmenella (sic) boisseli Bergeron, 1890 (= Calymenella boisseli) and Cryptolithus grenieri Bergeron, 1894 (= Onnia grenieri), the echinoderm Caryocrinites rugatus (Forbes, 1848) several indeterminate crinoid columnars, the bryozoans Monotrypa lens (McCoy, 1854) and Ptilodictya dichotoma
Portlock, 1847, and several molluscs such as Lophospira tropidophora (Meek, 1873), Cyclonema aff. pectinata (Barrande) and Tentaculites anglicus Salter, 1839. According to Hamman \& Leone (2007) the trilobite assemblage suggests a late Caradoc-early Ashgill age in the British scale.

With the systematic study of the brachiopod association described at the Montagne Noire preceding the Nicolella Community, we are aiming to analyse the environmental conditions of the region before the drastic changes in substrate, depth and temperature that brought the Boda event.

\section{Geographical and geological setting}

The Grand Glauzy hill, where this study has been undertaken, is midway between Gabian and Neffiès, in the Languedoc-Roussillon region of southern France. It belongs to the Cabrières Klippes (écailles de Cabrières) that form the eastern end of the southern slope of the Montagne Noire (Fig. 1). The Ordovician succession occurs there within olistoliths up to $1 \mathrm{~km}^{3}$ in size, inside a Carboniferous flysch succession (Feist \& Echtler 1994). The oldest deposits cropping out in the region are Early Ordovician sandy-argillaceous beds (Thoral 1946, Bérard 1986). Immediately overlying them, volcaniclastic deposits associated with interstratified andesitic lava flows appear (Gonord et al. 1964); they are dated as Mid-Ordovician by means of acritarchs (Martin fide Nysaether et al. 2002). Similar deposits of the same age occur in Sardinia (Helbing \& Tiepolo 2005). Nevertheless, they can be also compared with the Late Ordovician volcaniclastic rocks occurring in the Carnic Alps, the "Comelico-Porphyroid" and the Fleons 
Formation and their lateral equivalents, the Himmelberg Sandstone and the Uggwa Shale formations (Schönlaub \& Histon 2000). The quartzite beds studied herein overlie those volcaniclastic beds and underlie the very fossiliferous Upper Ordovician limestones and marls studied by Dreyfuss (1948) and Havlíček (1981) and still formally unnamed lithostratigraphically.

\section{Lithostratigraphy}

The first description of the Upper Ordovician sedimentary succession studied herein is by Graff (1874), which was subsequently refined by Dreyfuss (1948). No formal lithostratigraphic study of these beds has been made since, and important uncertainties arise with the introduction of new informal units to locate brachiopod fossiliferous horizons (Havlíček 1981). This author equates the "formation gréseuse" and the "calcaires et marnes schisteuses" of Dreyfuss (1948) with his "Clastic sequence" and "Carbonate sequence", respectively. However, from the study of the classic localities collected by both authors, it is clear that both Havlíček's (1981) Clastic and Carbonate sequences correspond to Dreyfuss's (1948) single unit "calcaires et marnes schisteuses”. Havlíček's (1981) Clastic sequence actually corresponds to the weathered and decalcified alternating limestones and marls that characterises the lower half of this unit, which crops out at the Tranchée Noire, west of Gabian. This is a long-time abandoned railway cutting, easy accessible until 1990, but which has become fully covered by vegetation in recent years. Because of rock decalcification, the fossils from this locality are beautifully preserved as internal and external moulds. With the term Carbonate sequence, Havlíček (1981) was referring to the non-decalcified remains of the same unit, cropping out close to the farmhouse "la Grange du Pin", also west of Gabian, and south of the Petit Glauzy hill, between Gabian and Neffiès. The brachiopods, bryozoans and echinoderms from these localities are mostly preserved as isolated shelly fossils, and have been collected since the $19^{\text {th }}$ century at the vineyards cultivated on the carbonate unit. Today most of the labour fields are abandoned, making it difficult to collect new fossils from them.

The "formation gréseuse" of Dreyfuss (1948) is actually a thickly bedded quartzitic unit, underlying the fossiliferous carbonatic beds studied by Havlíček (1981), which stands out in the landscape forming two neighbouring hills, the Grand Glauzy and the Petit Glauzy. To solve the confusion of this unit with the decalcified overlying carbonates, as noted above, it seems appropriate to undertake the formal erection of two successive lithostratigraphic units, with the rank of formation, according to the International Stratigraphic Guide (Hedberg 1976; North American Stratigraphic Commission 1983; Inter- national Subcommission on Stratigraphic Classification 1994, 1999).

\section{The Glauzy Formation}

Name derivation. - After the Grand Glauzy hill, $2 \mathrm{~km}$ west-northwest of Neffiès, where the unit best crops out.

Synonymy. - Grès à Trinucles (Bergeron 1889); formation gréseuse (Dreyfuss 1948); grès quartzitiques du Caradoc (Gonord et al. 1964).

Type section. - At the Grand Glauzy hill between Gabian and Neffiès, Languedoc-Roussillon region in southern France (Fig. 1). Geographic coordinates: $43^{\circ} 32^{\prime} 13^{\prime \prime} \mathrm{N}$; $3^{\circ} 18^{\prime} 21^{\prime \prime} \mathrm{E}$.

Lithology. - The thickness of this unit in the type section is about $50 \mathrm{~m}$. The base of the Formation is characterised by a few metres of coarse quartzitic sandstones with abundant centimetre-sized quartz pebbles. The rest of the unit is fairly homogeneous, and comprises dark grey quartzitic sandstones of medium grain rich in iron oxyhydroxides, disposed in cross-bedded layers from $10-20 \mathrm{~cm}$ to $4 \mathrm{~m}$ thick. Due to weathering the external surface of the sandstones has a reddish tinge. Within the uppermost thick beds of the unit, bioclast accumulations often occur.

Boundaries. - The lower limit is at the base of the first pebbly coarse sandstone bed overlying conformably volcaniclastic rocks. The upper limit is on the top of the uppermost sandstone bed, below the conformable alternating marls and limestones of the Gabian Formation, defined below (see Fig. 2).

Regional aspects. - The unit is only known between Neffiès and Laurens, Languedoc-Roussillon region (Engel et al. 1979), with a described maximum thickness of $90 \mathrm{~m}$ (Dreyfuss 1948).

Fossils. - The following taxa, in order of abundance, have been recorded: the brachiopods Proclinorthis vailhanensis Colmenar \& Villas gen. et sp. nov., Hedstroemina sp., Svobodaina havliceki Villas, 1985, Longvillia mediterranea Havlíček, 1981 and Triplesia? sp.; indeterminate crinoid columnar plates; the trilobites Dreyfussina exophthalma, Dalmanitina (Dalmanitina) proaeva, Calymenella boisseli and Onnia grenieri; the annelid Cornulites sp.; and undetermined ramose bryozoans.

Correlation with other units. - Considering its recorded brachiopods, the uppermost beds of the Glauzy Fm. can be correlated with the following intervals: the base of the 


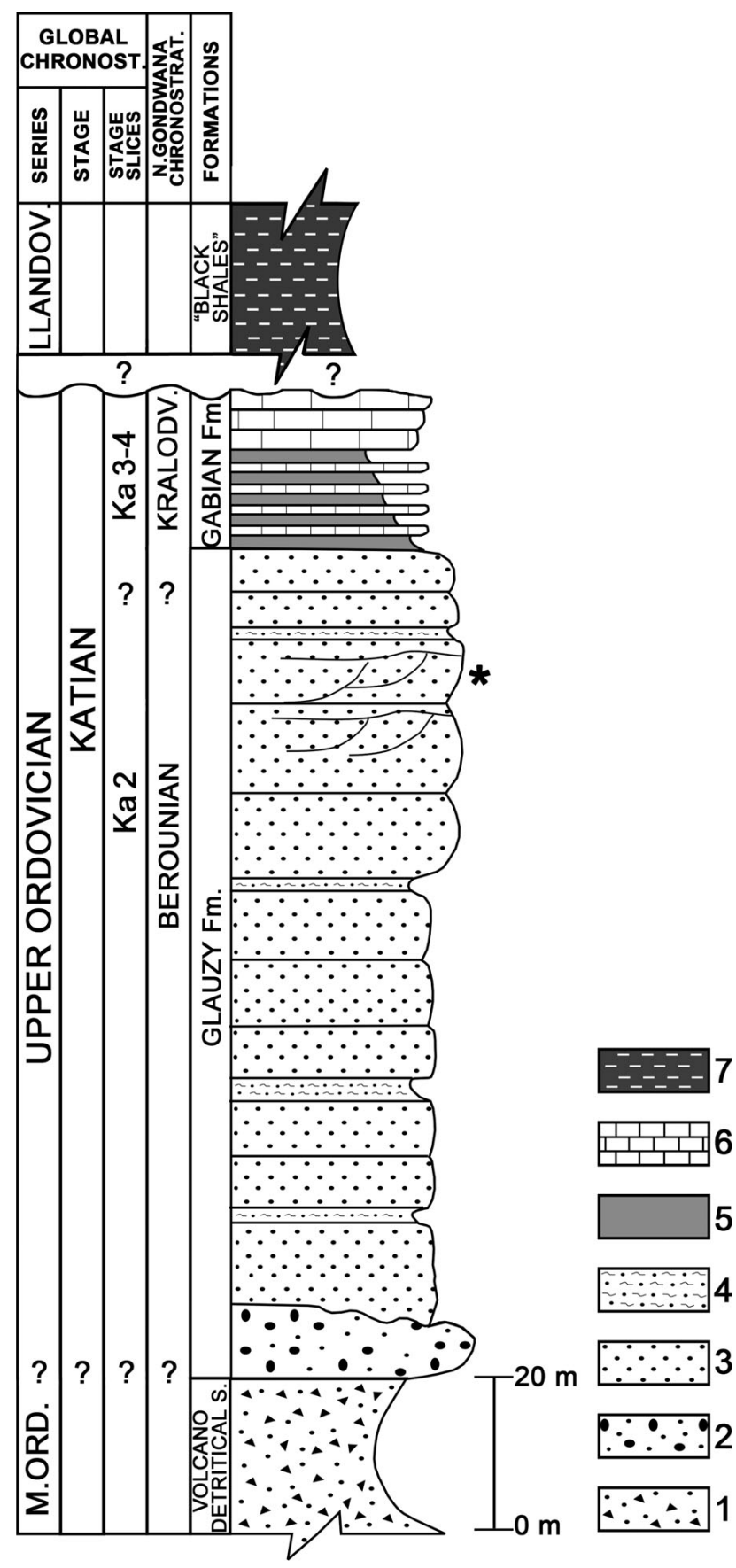

Figure 2. Schematic lithostratigraphic column. * - approximate provenance of the studied specimens. 1) volcaniclastic deposits; 2) conglomerates; 3) quartzitic sandstones; 4) sandy shales; 5) marlstones; 6) limestones.

Porto de Santa Ana Fm. from Buçaco, Portugal; the uppermost beds of the "Bancos Mixtos" in Central Iberia (Villas 1995); the upper half of Fombuena Fm. from the Iberian Chains, Spain (Villas 1985); the Cava Fm. from the Spanish Central Pyrenees (Gil-Peña et al. 2004); the base of the Portixeddu Fm. from Sardinia (Leone et al. 1991); the Uggwa Shale Fm. in the Carnic Alps, Austria (Havlíček et al. 1987); and the Upper Shale Member of the Bedinan Fm. in Turkey (Villas et al. 1995). Except for the Portuguese and the Austrian formations, those correlations are strengthened by the co-occurrence in the same units of the trilobites Dreyfussina exophtalma and Calymenella boisseli (see Hammann \& Leone 2007). Because no fossils are known from the lower half of the Glauzy Formation, no correlation can be attempted.

Age. - Based on the correlations described above and the dating of the basal horizons of the Porto de Santa Anna Fm. from Portugal as Pusgillian, by means of Chitinozoa (Paris 1979, 1981) and Acritarcha (Elaouad-Debbaj 1978), the highest beds of the Glauzy Formation can be dated as Katian, Ka2 stage slice (see Bergström et al. 2009). No dating is possible for the base of the unit.

\section{The Gabian Formation}

Name derivation. - After the Gabian village in the neighbourhood of the type section.

Synonymy. - Schistes à Orthis Actoniae et calcaires à Cystidés (Bergeron 1889); calcaires et marnes schisteuses (Dreyfuss 1948); Clastic and Carbonate sequences (Havlíček 1981).

Type section. - On the southern shoulder of the road D-13 between the villages of Gabian and Faugères, approximately $2 \mathrm{~km}$ west of Gabian. Geographic coordinates: $43^{\circ} 31^{\prime} 20^{\prime \prime} \mathrm{N} ; 3^{\circ} 15^{\prime} 05^{\prime \prime} \mathrm{E}$.

Lithology. - At its type section the lower part of the formation is characterised by $4.5 \mathrm{~m}$ of alternating marlstones with isolated shelly fossils and bioclastic limestone beds up to $10 \mathrm{~cm}$ thick. The upper part is made up of laminated massive bioclastic marly limestones rich in bryozoans and cystoids, of which only $2 \mathrm{~m}$ crops out below Quaternary beds. The total thickness of the unit was estimated at 10 to $25 \mathrm{~m}$ by Dreyfuss (1948).

Boundaries. - The lower limit is at the base of the first marly bed, conformably overlying the quartzitic sandstones of the Glauzy Formation (see Fig. 2). The upper limit in the type section cannot be observed because of the Quaternary covering, but it is tentatively placed on top of the uppermost massive bioclastic marly limestone bed. The lowermost Llandovery graptolitic black shales crop out close to the Petit Glauzy and Tranchée Noire sections (Centene \& Sentou 1975, Štorch \& Feist 2008). It is the oldest known unit above the Gabian Formation, but the type of contact between them is not known (Babin et al. 1988). 
Fossils. - Havlíček (1981) described the following brachiopods from the strata included herein in the Gabian Formation: Nicolella actoniae (Sowerby, 1839), Nicolella decemcostata Dreyfuss, 1948, Nicolorthis instans Havlíček, 1981, Eridorthis angustisulcata Havlíček, 1981, Dolerorthis cf. maxima (Vinassa, 1927), Tafilaltia trifida Havlíček, 1981, Tissintia glauziensis Havlíček, 1981, Heterorthis cf. alternata (Sowerby, 1839), Svobodaina feisti Havlíček, 1981, Svobodaina barnumosa Havlíček, 1981, Dalmanella rostrata Dreyfuss, 1948, Paucicrura cf. fascicula (Vinassa, 1927) [= Portranella exornata (Sharpe, 1853)], Drabovia cf. latior Havlíček, 1951, Protomendacella profuga Havlíček, 1981, Triplesia cymbula Havlíček, 1981, Leptestiina meloui Havlíček, 1981, Leangella anaclyta Havlíček, 1981, Aegiromena meneghiniana (Vinassa, 1927), Kozlowskites? sp., Strophomena sardoa Vinassa, 1927 (= Iberomena sardoa after Villas 1995), Longvillia mediterranea, Rafinesquina sp., Leptaena sp. A, Leptaena sp. B, Porambonites (Porambonites) magnus (Meneghini, 1880), Porambonites (Porambonites) dreyfussi Havlíček, 1981 and Eoanastrophia pentamera (Meneghini, 1857). Dreyfuss described the trilobite Dalmania socialis var. proaeva Emmrich, 1839 (=Dalmanitina proaeva). Ernst \& Key (2007) described 68 species of bryozoans from museum collections. Dreyfuss (1948) listed a total of 8 cystoid species. Babin et al. (1988) recorded some remains of the conodont Amorphognathus ordovicicus Branson \& Mehl, 1933.

Regional aspects. - The unit is only known between Neffiès and Laurens, in the Languedoc-Roussillon region (Engel et al. 1979) with a variable thickness between 10 and $25 \mathrm{~m}$ (Dreyfuss 1948). In addition to the type locality, it has been studied at the Tranchée Noire (Havlíček 1981), the abandoned railway cutting immediately south of the D-13 road, now fully covered by vegetation. A partial section of the unit can be studied at the cuttings by a small stream, a tributary of the Payne River, flowing immediately south of the Petit Glauzy hill, about $2 \mathrm{~km}$ westnorthwest of Neffiès.

Correlation with other units. - The fossil content of this formation, mainly consisting of characteristic elements of the brachiopod Nicolella Community, allows for correlation with other Upper Ordovician Mediterranean bioclastic limestones and dolostones, such as the Uggwa Limestone and Wolayer formations from the Carnic Alps, Austria (Schönlaub 1998), the Estana Fm. from the Spanish Central Pyrenees (Gil-Peña et al. 2004), the Cystoid Limestone from the Iberian Chains (Villas 1985), the Portixeddu and Domusnovas formations from Sardinia (Leone et al. 1991), the Rosan Fm. from the Armorican Massif (Mélou 1987), and the Upper Djeffara Fm. from Libya (Buttler \& Massa 1996).

Geologic age. - According to the correlation of the Medi- terranean formations bearing the Nicolella Community with the Pushgillian to Rawtheyan stages of the British scale (see Villas et al. 2002, fig. 1), the new formation can be dated as Katian (stage slices Ka2-Ka4) on the global scale. The finding of Amorphognatus ordovicicus within the unit (Babin et al. 1988) strengthens the correlation with the upper Katian (see Bergström et al. 2009).

\section{Systematic palaeontology}

The studied specimens are deposited in the "Muséum National d'Histoire Naturelle" of Paris. All the types and figured specimens appear here with the numbers MNHN.F.A46448 to MNHN.F.A46473 and MNHN.F.A47185 and the not figured specimens with the prefixed VOMN.

Abbreviations. - L - maximum valve length; $\mathrm{W}$ - maximum valve width; Lm - maximum length of muscle field; $\mathrm{Wm}$ - maximum width of muscle field; $\mathrm{vv}$ - ventral valve; $\mathrm{dv}-$ dorsal valve.

Order Strophomenida Öpik, 1934

Superfamily Strophomenoidea King, 1846

Family Strophomenidae King, 1846

Subfamily Strophomeninae King, 1846

\section{Genus Longvillia Bancroft, 1933}

Type species. - Longvillia grandis (Sowerby, 1839).

\section{Longvillia mediterranea Havlíček, 1981}

Figure $3 \mathrm{~A}-\mathrm{C}$

1910 Strophomena grandis Sow. - Vinassa, p. 42.

1927 Strophomena grandis - Vinassa, p. 479, pl. 4, fig. 1.

1927 Strophomena expansa - Vinassa, p. 480, pl. 4, fig. 2 (non fig. 3).

1929 Strophomena grandis Sow. - Heritsch, p. 112, pl. 1, figs 5,6 .

1981 Longvillia mediterranea sp. n. -Havlíček, p. 25, pl. 2, fig. 19; pl. 6, fig. 19; pl. 8, figs 12-16.

1987 Longvillia mediterranea Havlíček, 1981. - Havlíček et al., p. 307, pl. 4, figs 6-8; pl. 9, figs 3-7.

Material. - Internal and external moulds of three ventral valves MNHN.F.A46448, MNHN.F.A46449 and VOMN 2619.

Description. - Ventral valve of medium size (largest specimen $31 \mathrm{~mm}$ wide), semicircular in outline, with maximum width at posteromedial length or at hinge line, $62-76 \%$ as long as wide $(\overline{\mathrm{x}}=$ mean $=70 \% ; \mathrm{n}=$ number of specimens $=3$; 

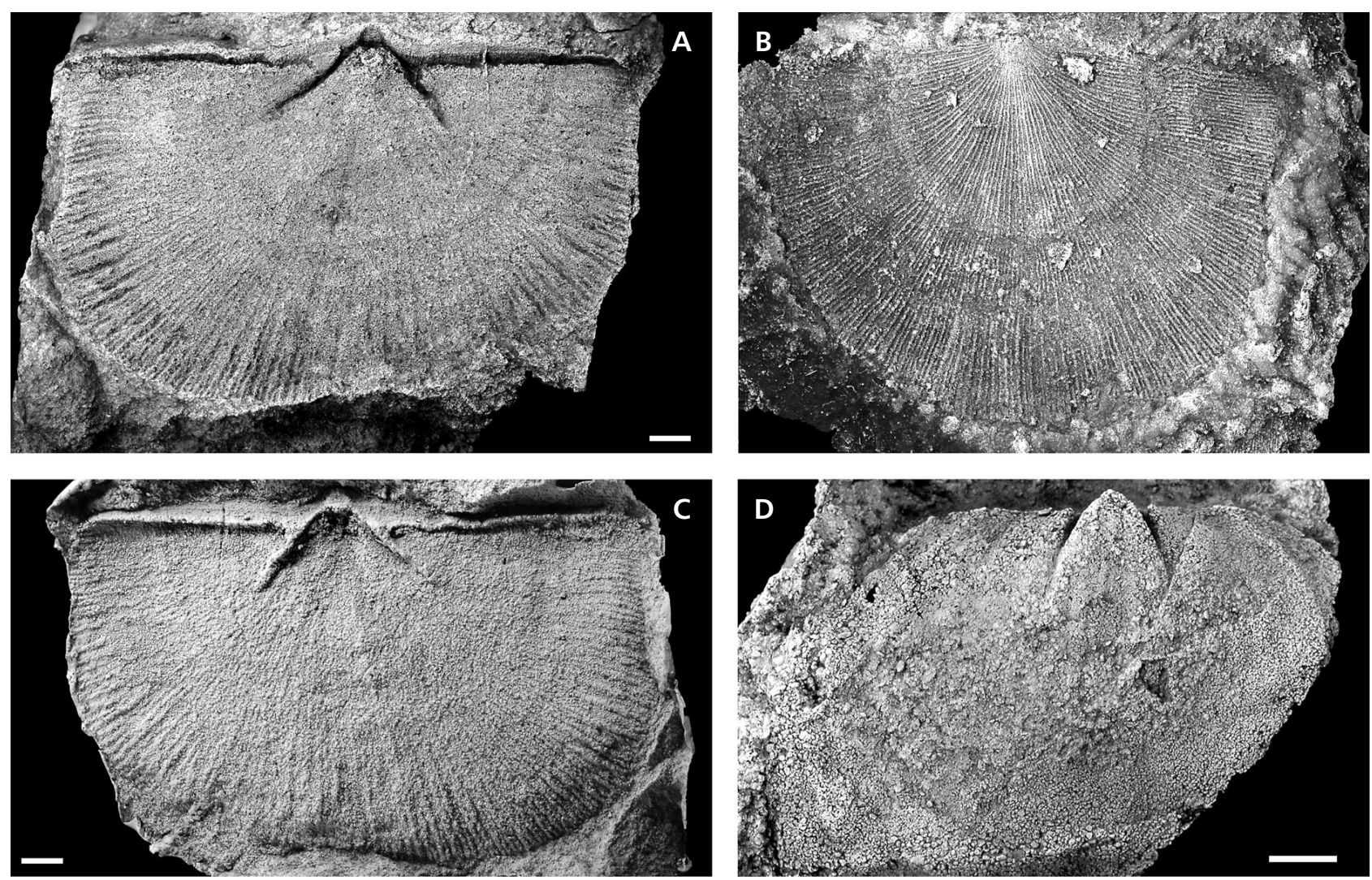

Figure 3. A-C - Longvillia mediterranea Havlíček, 1981; A, C - internal mould (A) and latex cast of interior (C) of ventral valve (MNHN.F.A46448); B - latex cast of exterior of ventral valve (MNHN.F.A46449). $\bullet$ D - Triplesia? sp.; internal mould of ventral valve (MNHN.F.A47185). Scale bar $=2 \mathrm{~mm}$.

$\sigma_{\mathrm{n}}=$ variance $\left.=0.06\right)$; moderately convex umbonal region and concave anterolaterally; obtuse to right cardinal angles; anterior commissure rectimarginate. Ventral interarea planar, apsacline, about $10 \%$ as long as valve length; delthyrium covered by pseudodeltidium. Radial ornament parvicostellate in early growth stages and multicostellate in adult stages, with 7-8 ribs per $2 \mathrm{~mm}, 10 \mathrm{~mm}$ anteromedially from umbo.

Ventral interior with divergent, thin, blade-like dental plates continuous anteriorly with short posterolaterally muscle bounding ridges extending forward from umbo approximately $25 \%$ of total valve length and diverging about 80 degrees; muscle field poorly impressed, large and flabellate, approximately $47 \%$ as long as valve length and $32 \%$ as wide as maximum valve width.

Remarks. - The studied valves can be clearly included within Longvillia mediterranea in spite of not having recorded any dorsal interior. The species was defined by Havlíček (1981) in the Montagne Noire, for shells collected from the Gabian Formation. The shells described above, collected from the underlying Glauzy Formation, do not differ significantly from Havlíček's type collection. L. mediterranea differs from the other species of the genus described to date in its multicostellate radial ornamentation in adult stages (Havlíček 1981), while Longvillia grandis (Sowerby, 1839), Longvillia asmusi (Verneuil, 1845) and Longvillia lanx Popov, 1985 are parvicostellate during their entire growth (Williams 1963, Rõõmusoks 1993 and Popov et al. 2002, respectively). Another criterion used by Havlíček (1981) to distinguish L. mediterranea from L. grandis, the difference in the ratio $\mathrm{Lm} / \mathrm{L}$ of the ventral valve, does not seem appropriate, because the muscle size of different specimens could be conditioned by ontogenetic or environmental parameters. In any case, it would be necessary to measure this ratio in a larger number of valves than Havlíček (1981) who measured only 3 of each species. Despite the absence of dorsal valves in the collection from the Glauzy Formation, its multicostellate adult radial ornamentation is a character exclusive enough within Longvillia to include it within L. mediterranea. The inclusion of this species within Longvillia is justified, among other features, by the thin socket ridges curving anteriorly, then laterally subparallel with hinge line, displayed by Havlíček's (1981) type collection.

Occurrence. - Cava Fm. and Estana Fm. from the Spanish Central Pyrenees; Porto de Santa Ana Fm. from Portugal; Uggwa Shales Fm. from the Carnic Alps, Austria (Havlíček et al. 1987); Portixeddu Fm. from Sardinia, Italy (Havlíček 

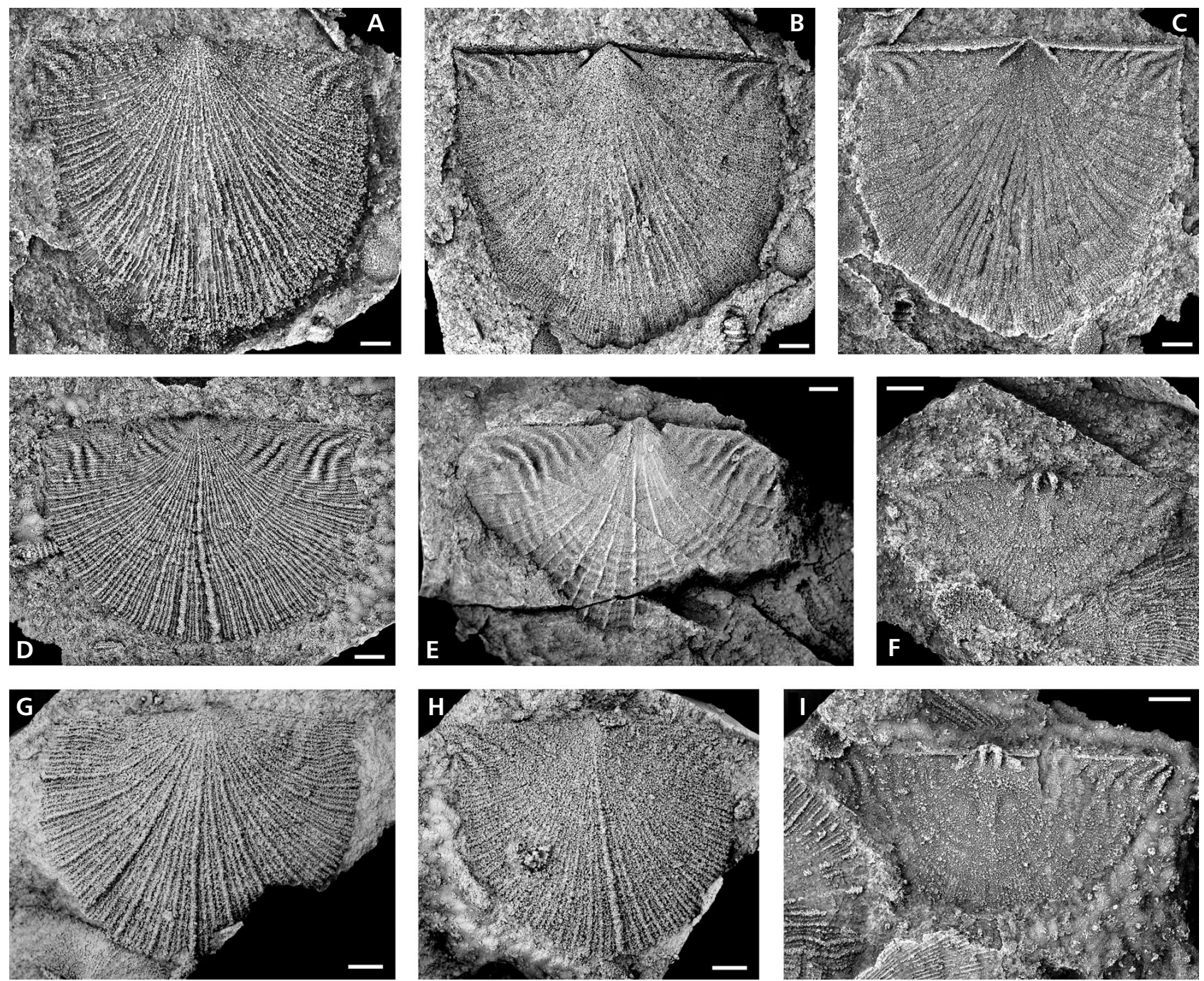

Figure 4. Hedstroemina $\mathrm{sp}$. (scale bar $=2 \mathrm{~mm})$. A-C - latex cast of exterior $(\mathrm{A})$ and interior $(\mathrm{C})$ and internal mould (B) of ventral valve showing anterior geniculation (MNHN.F.A46450). $\bullet$ D - latex cast of exterior of ventral valve showing accentuated median costella (MNHN.F.A46451). $\bullet$ E - internal mould of ventral valve showing concentric rugae (MNHN.F.A46452). $\bullet \mathrm{F}$ - latex cast of dorsal valve interior (MNHN.F.A46453). $\bullet \mathrm{G}-$ latex cast of exterior of ventral valve (MNHN.F.A46454). $\bullet$ H - latex cast of exterior of ventral valve (MNHN.F.A46455). $\bullet$ I - latex cast of dorsal valve interior (MNHN.F.A46456).

et al. 1987); Glauzy and Gabian Fms from the Montagne Noire.

Family Rafinesquinidae Schuchert, 1893

Subfamily Rafinesquininae Schuchert, 1893

\section{Genus Hedstroemina Bancroft, 1929}

Type species. - Hedstroemina fragilis Bancroft, 1929.

\section{Hedstroemina sp.}

Figure 4A-I

Material. - Internal and external moulds of 27 ventral valves and four dorsal valves (MNHN.F.A46450 to
MNHN.F.A46456 and VOMN 696, 704, 709, 710, 714, 727.2, 735, 743, 2167, 2168, 2171', 2175, 2176, 2179, 2180, 2188, 2191, 2200, 2610, 2611, 2620).

Description. - Shells of medium size (largest specimen $24 \mathrm{~mm}$ wide), concavoconvex, parallel-sided to semicircular in outline, or weakly alate in some specimens; maximum valve width at hinge line in most specimens, and more rarely slightly anteriorly to hinge line; slightly acute to rectangular cardinal angles and rectimarginate anterior commissure. Ventral valve ranging $63-100 \%$ as long as wide $\left(\overline{\mathrm{x}}=82 \% ; \mathrm{n}=16 ; \sigma_{\mathrm{n}}=0.11\right)$ and $7-20 \%$ as deep as long $\left(\bar{x}=10 \% ; n=16 ; \sigma_{n}=0.03\right)$; moderately convex umbonal region and subplanar disc, weakly geniculate dorsally at $17 \mathrm{~mm}$ long growth stage in the largest studied specimen (Fig. 4A, B). Ventral interarea planar, apsacline, 
$7-13 \%$ as long as valve length, delthyrium partially covered by apical pseudodeltidium. Dorsal valve with concave lateral profile, dorsal interarea anacline. Radial ornament unequally parvicostellate with $7-10$ ribs per $2 \mathrm{~mm}$ at $5 \mathrm{~mm}$ anteromedianly from umbo, with 4-5 costellae intercalated between two costae; all of them with rounded tops; with prominent median costa in a few ventral valves. Concentric ornamentation of growth fila and variably developed discontinuous rugae, on posterolateral sides of valves, running oblique to hinge line; only a single specimen (Fig. 4E) with continuous rugae covering the entire valve.

Ventral interior with divergent, thin, blade-like dental plates extending forward approximately $10 \%$ of valve length and average dental plates divergence angle of $92^{\circ}$ (range $79-114^{\circ} ; \mathrm{n}=13$ ); muscle field very poorly impressed. Dorsal interior with strong and divergent socket ridges bounding triangular and elongated dental sockets; bifid cardinal process with ponderous, laminar and weakly divergent lobes on low notothyrial platform, continuous with broad median ridge (Fig. 4F, I); dorsal muscle field weakly elongated, about $90 \%$ as long as wide $(\mathrm{n}=1)$.

Remarks. - The described shells are clearly included within the subfamily Rafinesquininae for their cardinalia, but their generic attribution merits some discussion. They share diagnostic features with Hedstroemina as well as with Kjaerina, two such close taxa that Williams (1974) considered Hedstroemina to be a Kjaerina subgenus. Nevertheless, Hurst (1979), Harper (in Owen \& Harper 1982), Cocks \& Rong (2000) and Cocks (2010) distinguished them as independent genera, differentiating them by the geniculation, the radial and the concentric ornamentation, and the extension and divergence of the dental plates. The studied valves are no larger than $22 \mathrm{~mm}$, probably belonging to young specimens that have not developed yet the dorsal geniculation, with the exception of a single ventral valve (Fig. 4A, B). According to the incipient geniculation developed on the anterior margin, our material can be included within Hedstroemina, which is characterised by a weak dorsal geniculation anteriorly, while $\mathrm{Kja}$ erina develops its geniculation in the posterior margin of the valve (Cocks \& Rong 2000). An accentuated median costella, a feature considered diagnostic of Kjaerina (see Cocks \& Rong 2000), is displayed by only a few of the studied valves, suggesting that this is a variable intraspecific feature and should be excluded from the rafinesquinin generic diagnoses. The variably developed rugae on the studied valves does not allow us to distinguish between Hedstroemina and Kjaerina, because this is a feature described for both genera, although employing different terms: fine irregular rugae in Kjaerina and impersistent concentric wrinkles in Hedstroemina (Hurst
1979, Cocks \& Rong 2000). Cocks (2010) also stated that valve corrugation is a variable intraspecific feature and should not be considered diagnostic at the genus level. This is in agreement with the great variability of this feature in our material. So despite the fact that the ornamentation is more similar to that shown by the Kjaerina type species lectotype than to the ornamentation shown by the Hedstroemina type species lectotype, these characters have not been considered here. The dental plates not extending forward to enclose the ventral muscle field as well as their wide divergence are also characters typical of Hedstroemina and allow us to distinguish the studied shells from Kjaerina. Based on the characters with less variability such as the geniculation and the extension and divergence of the dental plates we assign the described material to Hedstroemina. Nevertheless, a larger sample allowing for more precise study of the geniculation in adult shells is needed to confirm the generic assignation and to attempt the specific identification.

Order Orthotetida Waagen, 1884

Suborder Triplesiidina Moore, 1952

Superfamily Triplesioidea Schuchert, 1913

Family Triplesiidae Schuchert, 1913

\section{Genus Triplesia Hall, 1859}

Type species. - Triplesia extans (Emmons, 1842).

\section{Triplesia? sp.}

Figure 3D

Material. - External and internal moulds of one incomplete ventral valve MNHN.F.A47185.

Description. - Ventral valve transversely oval in outline with obtuse cardinal angles. Hinge line short, about $50 \%$ as wide as maximum width; lateral profile gently convex in umbonal region and more planar laterally; median shallow sulcus developed anteriorly; smooth valve surface.

Ventral interior with short, strong, divergent laminar dental plates, extending forward from umbo $8 \%$ of valve length; poorly impressed triangular-shaped muscle scar.

Remarks. - The shallow ventral sulcus, the dental plates and the smooth ornamentation allow including tentatively the specimen into the genus Triplesia. Due to the scarcity of the studied material and the absence of diagnostic features, as those related to the interarea and the delthyrium in the only specimen available, we prefer to leave the generic assignation with open nomenclature. It is not possible either to make a specific assignation. 

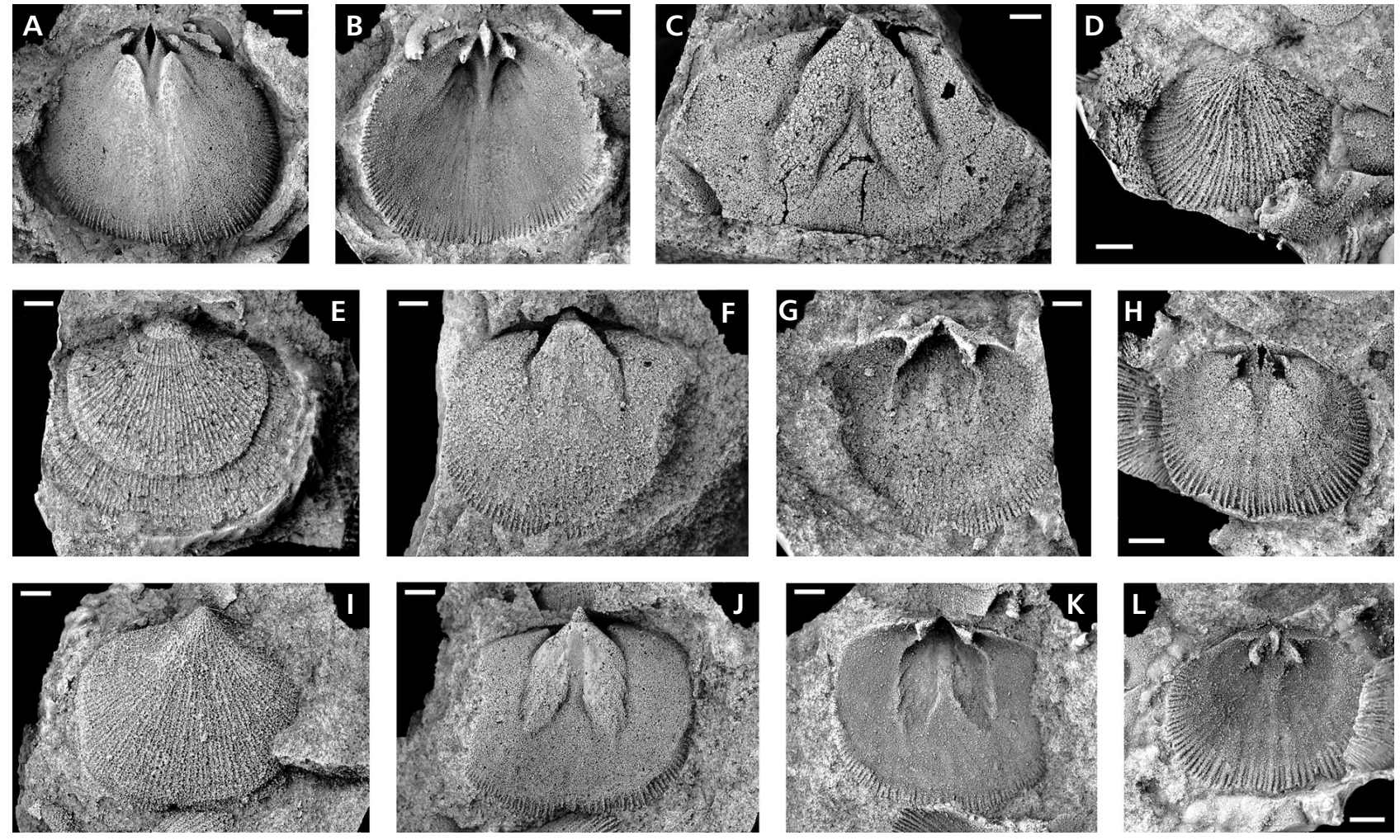

Figure 5. Svobodaina havliceki Villas, 1985 (scale bar $=2 \mathrm{~mm}$ ). - A, B - internal mould (A) and latex cast of interior (B) of dorsal valve (MNHN.F.A46457). $\bullet$ C - internal mould of ventral valve of a gerontic specimen (MNHN.F.A46458). $\bullet$, H, L - latex cast of exterior (D) and interior (L) and internal mould $(\mathrm{H})$ of dorsal valve (MNHN.F.A46459). $\bullet \mathrm{E}-\mathrm{G}$ - latex cast of exterior (E) and interior $(\mathrm{G})$ and internal mould (F) of ventral valve (MNHN.F.A46460). $・ \mathrm{I}-\mathrm{K}-$ latex cast of exterior (I) and interior (K) and internal mould (J) of ventral valve (MNHN.F.A46461).

Order Orthida Schuchert \& Cooper, 1932

Suborder Dalmanellidina Moore, 1952

Superfamily Dalmanelloidea Schuchert, 1913

Family Heterorthidae Schuchert \& Cooper, 1931

\section{Genus Svobodaina Havlíček, 1951}

Type species. - Svobodaina ellipsoides (Barrande, 1848).

\section{Svobodaina havliceki Villas, 1985}

Figure 5A-L

1971 Svobodaina cf. inclyta (Barr.). - Vai, pl. 3, fig. 3.

1971 Heterorthis aff. retrorsistria (M'Coy). - Vai, pl. 3, fig. 4.

1979 Svobodaina sp. - Hafenrichter, pl. 9, fig. 10.

1983 Svobodaina ellipsoides (Barrande). - Villas, pl. 2, figs 5-7.

1985 Svobodaina havliceki sp. nov. - Villas, p. 55, pl. 10, figs 1-10; pl. 11, figs 1-10.

1991 Svobodaina havliceki Villas, 1985. - Leone et al., pl. 1 , figs $1-3$.

Material. - Internal and external moulds of 11 ventral valves and 14 dorsal valves: MNHN.F.A46457 to MNHN.F.A46461 and VOMN 692, 703, 719, 727.2, 736, 799, 2156, 2164, 2166, 2170a.2, 2193, 2195, 2196, 2615, 2616, 2639, 2641.a, 2652, 2709, 2733 b.

Description. - Strongly dorsibiconvex valves of medium size (largest specimen about $22 \mathrm{~mm}$ wide), subcircular to transversely suboval in outline, with obtuse cardinal angles and maximum width at anteromedial length. Hinge line relatively short, about $45 \%$ as wide as maximum width; anterior commissure rectimarginate or very slightly unisulcate. Ventral valve ranging $65-92 \%$ as long as wide $(\overline{\mathrm{x}}=84 \%$; $\left.\mathrm{n}=11 ; \sigma_{\mathrm{n}}=0.08\right)$ and $9-24 \%$ as deep as long $(\overline{\mathrm{x}}=15 \%$; $\left.\mathrm{n}=11 ; \sigma_{\mathrm{n}}=0.04\right)$, maximum depth at posteromedial region; lateral profile with moderately elongated umbo. Ventral interarea planar apsacline, $8-17 \%$ as long as valve length, delthyrium open. Dorsal valve ranging $69-100 \%$ as long as wide $\left(\overline{\mathrm{x}}=87 \% ; \mathrm{n}=14 ; \sigma_{\mathrm{n}}=0.08\right)$ and $9-34 \%$ as deep as long $\left(\bar{x}=20 \% ; n=13 ; \sigma_{n}=0.06\right)$; lateral profile weakly convex in early growth stages and strongly convex during the following stages of growth; shallow median sulcus attenuated anteriorly. Dorsal interarea orthocline, $7-16 \%$ as long as valve length; open notothyrium. Radial ornament fascicostellate with $6-8$ ribs 
per $2 \mathrm{~mm}, 5 \mathrm{~mm}$ anteromedianly from umbo, with rounded tops. A few specimens show up to two strong growth lines (Fig. 5E).

Ventral interior with strong divergent dental plates extending forward as muscle bounding ridges approximately $24 \%$ of valve length; flabellate muscle field ranging $41-74 \%$ as long as valve $\left(\bar{x}=57 \% ; n=7 ; \sigma_{n}=0.1\right)$, and from $25-52 \%$ as wide as maximum valve width $\left(\overline{\mathrm{x}}=38 \% ; \mathrm{n}=10 ; \sigma_{\mathrm{n}}=0.07\right)$. Diductor scars with sub-parallel sides in young to mature shells, to moderately divergent sides in gerontic shells (Fig. 5C), much longer than adductor scars, and not enclosing them anteriorly. Adductor scars with subparallel lateral margins and $12 \%$ as wide as maximum muscle field width. Pedicle callist well developed extending $0.7-1.5 \mathrm{~mm}$ anteriorly from umbo (Fig. 5F, G, J, K).

Dorsal interior with blade-like brachiophores, with relatively strong bases convergent onto median ridge sides, extending forward from umbo approximately $21 \%$ of valve length, delimiting laterally a well-developed rhomboidalshaped notothyrial platform continues with median ridge extending forward up to $68 \%$ of valve length. Cardinal process trilobed, with an elongated mid-lobe ranging from 150 to $400 \%$ as long as cardinal process width, differentiated in myophore and shaft in $10 \%$ of specimens, rest of specimens cardinal process undifferentiated. Adductor muscle field quadripartite averaging $42 \%\left(\mathrm{n}=11 ; \sigma_{\mathrm{n}}=0.09\right)$ as long as valve length and $45 \%\left(\mathrm{n}=13 ; \sigma_{\mathrm{n}}=0.09\right)$ as wide as maximum width of valve, halved by median ridge. Posterior pair of adductor scars subtriangular and smaller than the subcircular anterior pair.

Remarks. - The subcircular to transversely suboval outline of ours specimens, the dorsibiconvex profile, the short hinge line, the large and flabellate ventral muscle field, and the trilobed cardinal process with ovoid base, are the main features that allow us to classify our specimens as Svobodaina. The criteria used by several authors to differentiate among the three Mediterranean species (S. armoricana Babin \& Melou, 1972, S. feisti Havlíček, 1981 and S. havliceki Villas, 1985), that is the ratios $\mathrm{Lm} / \mathrm{L}$ and $\mathrm{Wm} / \mathrm{W}$ of the ventral muscle field, are inconclusive because the ratios overlap in the three species in their type localities. S. armoricana ranges $42-61 \%$ as long as valve length and $32-48 \%$ as wide as maximum valve width, $S$. feisti ranges $50-79 \%$ as long as valve length and $30-50 \%$ as wide as maximum valve width and $S$. havliceki ranges $54-82 \%$ as long as valve length and 36-95\% as wide as maximum valve width. We propose the use of additional criteria, such as the variations in the ventral muscle field outline, to complement those used previously. Following these guidelines, the differentiation between $S$. havliceki and the two other Mediterranean species is clear, because the former has much more scalloped external margins of diductor scars and more divergent anterior ends of the ventral muscle field, as in the case of the specimens studied.

Occurrence. - Glauzy Fm. from the Montagne Noire (France). Cava Fm. from the Spanish Central Pyrenees (Gil-Peña et al. 2004), uppermost "Bancos Mixtos" from the Central Iberian Zone (Villas 1995), and uppermost Fombuena Fm. from the Iberian Chains, Spain (Villas 1985). Porto de Santa Ana Fm. from Portugal; Portixeddu Fm. from Sardinia, Italy (Leone et al. 1991); Uggwa Shale Fm. from the Carnic Alps, Austria.

Family Platyorthidae Harper, Boucot \& Walmsley, 1969

Genus Proclinorthis gen. nov.

Type species. - Proclinorthis vailhanensis gen. et sp. nov.

Etymology. - Referring to its procline ventral interarea.

Diagnosis. - Shell subcircular to transversely suboval, unisulcate, strongly dorsibiconvex to almost convexiplane with short hinge line and obtuse rounded cardinal angles; radial ornamentation ramicostellate; ventral interarea procline, dorsal interarea anacline to orthocline; ventral interior with flabellate muscle field; divergent diductor scars enclosing anteriorly lanceolate adductor scars; dorsal interior with rod-like divergent brachiophores; cardinal process trilobed and undifferentiated.

Remarks. - The studied valves show characters in common with various genera belonging to the Heterorthidae Schuchert \& Cooper, 1931 and Platyorthidae Harper, Boucot \& Walmsley, 1969, both groups with a family taxonomic status as currently considered (Williams \& Harper 2000). In both families the cardinal process, the brachiophores and the muscle field are considered as characters of high systematic value (Harper et al. 1969, Havlíček 1970). Historically difficulties have occurred in the discrimination of some dalmanelloid genera between these families, due to their similar characters. The platyorthids were first considered a subfamily within the family Rhipidomellidae Schuchert, 1913 (Harper et al. 1969), where the heterorthids and the rhipidomellids were also included as subfamilies. Among the diagnostic features selected by Harper et al. (1969) to separate the Platyorthinae and the Heterorthinae there was no character exclusive to one of the two groups, with some genera of the Platyorthinae having characters diagnostics of the Heterorthinae and vice versa. Although both groups are currently considered independent families, Platyorthidae and Heterorthidae, the similarity between them is patently obvious, with difficulties in assigning some genera to one of them. This is the case for 
Diceromyonia Wang, 1949 proposed by Boucot et al. (1965) to be a member of the heterorthids and thereafter assigned to the platyorthids by Harper et al. (1969), where it was kept by Williams \& Harper (2000). This is also the case of Crozonorthis Mélou, 1976, assigned to the family Heterorthidae by its author, then considered by Havlíček (1977) a junior synonym of Eorhipidomella Hints, 1971 and moved subsequently, as well as Eorhipidomella, to the family Platyorthidae by Williams \& Harper (2000).

Although the new genus shows characters in common with heterorthids and platyorthids, the greatest similarities are with the platyorthids, such as the short hinge line, the strongly dorsibiconvex longitudinal profile, the diductor scars enclosing adductors, the rod-like brachiophores and the trilobed cardinal process.

The strongly dorsibiconvex longitudinal shell profile recalls the genus Crozonorthis present in the Darriwilian from France and Iberia. The short hinge line is common to most of the platyorthid genera, as is the presence of a dorsal median sulcus. The ramicostellate radial ornamentation also occurs in Eorhipidomella and Crozonorthis. The presence of a pedicle callist is also typical of Platyorthis, although rare in other platyorthids. The ventral muscle field outline is similar to that of Crozonorthis, Diceromyonia, Eorhipidomella and Platyorthis, and, as in the rest of platyorthids, except Marklandella, the adductor scars are enclosed anteriorly by diductor scars. This is a character diagnostic of the family Platyorthidae and one of the main differences with the family Heterorthidae (Harper et al. 1969). Other character shared by the new genus and other platyorthids, such as Crozonorthis, Eorhipidomella and Platyorthis, is the presence of a median ridge that separates the anterior part of the ventral diductor scars. The rod-like brachiophores are characteristics of the platyorthids except Diceromyonia, but it is noteworthy that the brachiophores differ from the remaining genera in lacking brachiophore bases. The notothyrial platform is reduced and is totally taken up by the cardinal process, as occurs in Marklandella, Crozonorthis and Diceromyonia. The cardinal process is trilobed as in the rest of the platyorthids excepting Diceromyonia, which has an elongated blade-like cardinal process. On the other hand the presence in our specimens of an undifferentiated cardinal process is a character only shared with Platyorthis and Elsaella within the family Platyorthidae.

The major difference with all the platyorthid genera is in the ventral interarea, which is procline, while in the platyorthids the standard is apsacline (Marklandella, Crozonorthis, Diceromyonia) and to a lesser extent orthocline or orthocline to apsacline (Eorhipidomella and Platyorthis, respectively).

The studied specimens are closely related to Crozonorthis, Eorhipidomella and Platyorthis, but the differences between them and all the other platyorthids in the interareas attitude and cardinalia, among others, are significant enough to create a new genus within the family to embrace them.

\section{Proclinorthis vailhanensis sp. nov. Figure 6A-Z}

Holotype. - MNHN.F.A46467, internal mould of a pedicle valve (Fig. 5M, P).

Paratypes. - MNHN.F.A46462 to MNHN.F.A46466 and MNHN.F.A46468 to MNHN.F.A46473 (Fig. 5A-L, $\mathrm{N}, \mathrm{O}, \mathrm{Q}-\mathrm{Z})$.

Type locality. - Grand-Glauzy hill southern slope, Vailhan, Hérault departament (Languedoc-Roussillon region, France).

Type horizon. - Thickly bedded quarzitic sandstones of the upper part of the Glauzy Formation.

Material. - Internal and external moulds of 29 ventral valves and 34 dorsal valves: MNHN.F.A46462 to MNHN.F.A46473 and VOMN 701, 720, 721, 727.1, 758, 764, 767, 780, 1659a', 2158, 2162, 2163, 2165, 2169, 2170a.3-5, 2170c.1-3, 2170c.5-8, 2177.3, 2178, 2181.1-2, 2183, 2184, 2186, 2199, 2201, 2612, 2614, 2616, 2617, 2622a, b, 2624, 2625a, b, 2640.2, 2641b, 2642, 2645, 2648, 2650, 2706, 2708, 2733a, b.

Etymology. - From Vailhan, its type locality.

Diagnosis. - As for the genus.

Description. - Shell strongly dorsibiconvex to almost convexiplane of medium size (largest specimen about $12 \mathrm{~mm}$ wide), subcircular to transversely suboval in outline, with obtuse and rounded cardinal angles and maximum width at anteromedial length. Hinge line relatively short, about 55\% as wide as maximum width; anterior commissure unisulcate. Ventral valve slightly convex to subplanar, 64-96\% as long as wide $\left(\overline{\mathrm{x}}=76 \% ; \mathrm{n}=29 ; \sigma_{\mathrm{n}}=0.08\right)$ and $8-15 \%$ as deep as long $\left(\overline{\mathrm{x}}=10 \% ; \mathrm{n}=29 ; \sigma_{\mathrm{n}}=0.05\right)$, maximum depth at posterior region; lateral profile with moderately convex umbonal region, flat laterally. Ventral interarea planar, procline (see Fig. 6P), 5-24\% as long as valve length, delthyrium open. Dorsal valve $66-96 \%$ as long as wide $\left(\overline{\mathrm{x}}=82 \% ; \mathrm{n}=34 ; \sigma_{\mathrm{n}}=0.07\right)$ and $15-30 \%$ as deep as long $\left(\overline{\mathrm{x}}=25 \% ; \mathrm{n}=34 ; \sigma_{\mathrm{n}}=0.04\right)$. Dorsal valve strongly convex, with a shallow median sulcus; dorsal interarea anacline to orthocline, 6-15\% as long as valve length, with open notothyrium filled completely by cardinal process. Radial ornament ramicostellate with $10-12$ ribs per $2 \mathrm{~mm}$ at $5 \mathrm{~mm}$ 
anteromedianly from umbo; ribs straight, with rounded tops that near cardinal angles turn postero-laterally to intersect hinge line.

Ventral interior with anteriorly divergent dental plates, extending forward from umbo approximately $20 \%$ of valve length and continuous anteriorly with muscle bounding ridges; flabellate muscle field very large, $80 \%$ as long as valve in largest valves $\left(\overline{\mathrm{x}}=52 \% ; \mathrm{n}=23 ; \sigma_{\mathrm{n}}=0.08\right)$, $35-62 \%$ as wide as maximum valve width $(\overline{\mathrm{x}}=43 \%$; $\mathrm{n}=25 ; \sigma_{\mathrm{n}}=0.06$ ), with lanceolate adductor scars about one-quarter as wide as entire muscle field, enclosed anteriorly by diductors. Diductor scars with sub-parallel sides in small specimens and scalloped and divergent sides in larger ones, bisected in front of adductor scars by thin median ridge. Pedicle callist only present in larger specimens (Fig. 6M, P).

Dorsal interior with rod-like divergent brachiophores with very reduced bases, extending forward from umbo approximately $23 \%$ of valve length, with posterior ends bounding externally deep dental sockets and internally small notothyrial platform, which is practically a posterior thickening of median ridge; cardinal process undifferentiated, trilobed, elliptical in outline, taking up the entire notothyrial platform and protruding through notothyrium. Adductor muscle field $27-66 \%$ as long as valve length $\left(\overline{\mathrm{x}}=52 \% ; \mathrm{n}=15 ; \sigma_{\mathrm{n}}=0.12\right)$ and $23-54 \%$ as wide as maximum valve width $\left(\overline{\mathrm{x}}=30 \% ; \mathrm{n}=42 ; \sigma_{\mathrm{n}}=0.08\right)$; adductor scars separated by $1.7-6.4 \mathrm{~mm}$ long median ridge; adductor pits present.

Endopunctae radially arranged in outer margin of both valves coinciding with rib impressions (Fig. 6F, X).

\section{Palaeoecology}

The brachiopod shells studied here come from skeletal accumulations within thick beds of quartzitic mediumgrained sandstone with cross bedding, near the top of the Glauzy Formation. The depositional environment is inferred to be a shallow-marine shelf, with a shifting sand substrate in a high-energy environment. All of the studied shells occur disarticulated and randomly oriented, accumulated much probably by the action of storms.
The brachiopod assemblage is of low diversity, as may be expected in a benthic community from a shallow environment with a siliciclastic substrate (Johnson 1972). It includes valves of Proclinorthis vailhanensis (44\%), Hedstroemina sp. (34\%), Svobodaina havliceki (17\%), Longvillia mediterranea (4\%), Triplesia? sp. (1\%) (see Fig. 7). These percentages, calculated using the numbers of the most abundant valve of each species, as well as the ratios of ventral to dorsal valves of each species, as indicated below, have been calculated from a sample of 123 brachiopod valves. In addition to brachiopods, on which we focused our study, the assemblage also includes disarticulated trilobite exoskeletons of the species Dreyfussina exophthalma, Dalmanitina proaeva, Calymenella boisseli and Onnia grenieri, the encrusting annelid Cornulites sp., as well as bryozoans and very abundant indeterminate crinoid columnar plates.

This kind of accumulations can be constituted by assemblages of taxa that in origin inhabited different environments and areas more or less distant from the final accumulation zone of the remains. In order to verify their relative autochthony and to identify the different benthic communities that could be represented in the assemblage, a taphonomic analysis and a functional morphology analysis of the preserved brachiopods have been carried out.

\section{Taphonomic analysis}

As happens with bivalves, the brachiopod valves show a different hydrodynamic behaviour depending on their size, weight and morphology (Simões et al. 2005). Generally, ventral and dorsal valves of brachiopods show these differences not only among species, but also intraspecifically, mainly due to morphological changes during ontogeny.

During a storm, the brachiopods living on the sea bottom are disarticulated, fragmented and got in suspension. Because of their different morphologies, each valve will behave differently, producing an important bias in shallow shelf environments, as a result of the differential transport of the valves (Hallman et al. 1996, Simões \& Kowalewski 2003). One of the factors that primarily controls the transport suffered by a valve is the settling speed (Simões et al.

Figure 6. Proclinorthis vailhanensis gen. et sp. nov. (scale bar $=2 \mathrm{~mm})$. $\bullet$ A-C - paratype, latex cast of exterior $(\mathrm{A})$ and interior $(\mathrm{C})$ and internal mould (B) of ventral valve (MNHN.F.A46462). - D, H - paratype, internal mould (D) and latex cast of interior (H) of ventral valve (MNHN.F.A46463). - E-G - paratype, latex cast of exterior (E) and interior $(\mathrm{G})$ and internal mould (F) of ventral valve (MNHN.F.A46464). $\bullet$ I, J - paratype, internal mould (I) and latex cast of interior (J) of ventral valve (MNHN.F.A46465). $\bullet$ K, L - paratype, internal mould (K) and latex cast of interior (L) of dorsal valve (MNHN.F.A46466). $\bullet \mathrm{M}, \mathrm{P}$ - holotype, internal mould (M) and lateral oblique view of latex cast of interior, showing the procline interarea (P) of ventral valve (MNHN.F.A46467). $\bullet$ N, O - paratype, internal mould (N) and latex cast of interior (O) of dorsal valve (MNHN.F.A46468). $\bullet$ Q, R - paratype, internal mould (Q) and latex cast of interior (R) of dorsal valve (MNHN.F.A46469). $\bullet$ S, T - paratype, latex cast of exterior (S) and internal mould (T) of dorsal valve (MNHN.F.A46470). $\bullet$ U, V - paratype, internal mould (U) and latex cast of interior (V) of dorsal valve (MNHN.F.A46471). $\bullet$ W, Y - paratype, latex cast of exterior $(\mathrm{W})$ and interior $(\mathrm{Y})$ and internal mould $(\mathrm{X})$ of dorsal valve (MNHN.F.A46472). $\bullet \mathrm{Z}-$ paratype, latex cast of interior of dorsal valve (MNHN.F.A46473). 

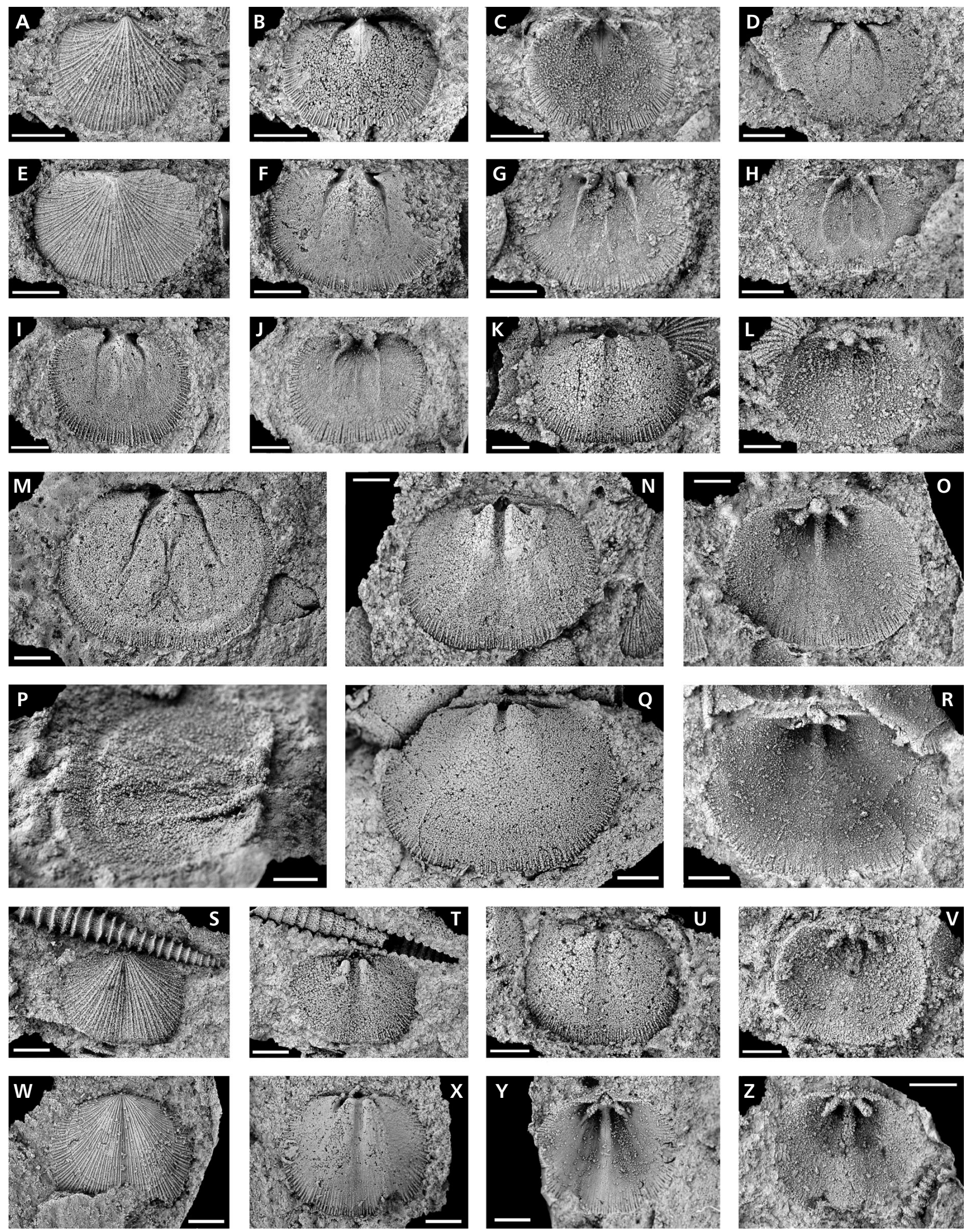


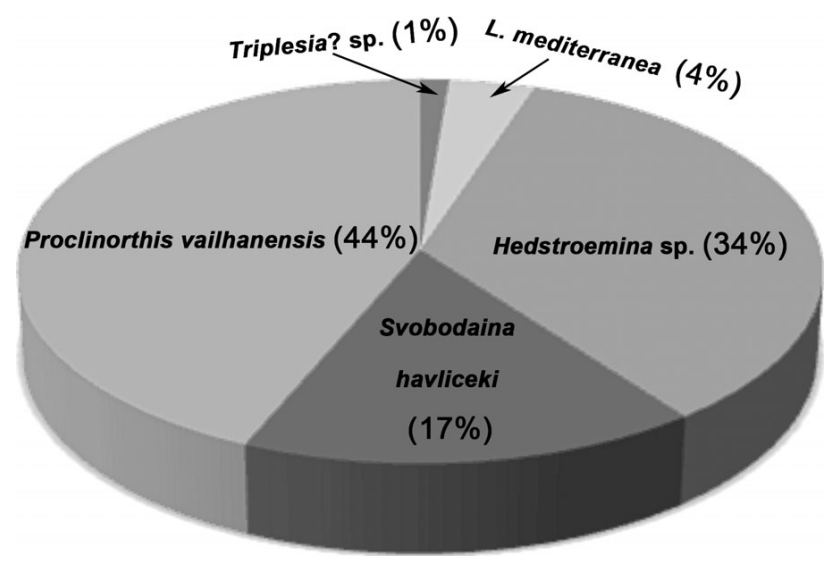

Figure 7. Pie chart showing the relative abundance of each brachiopod taxon in the Glauzy Formation.

2005), or the speed of descent reached by a skeleton from a certain height of the water column. The slower the settling speed, the longer the valve remains in suspension in the water column, and the more susceptible it is to be transported across large distances. According to Simões et al. (2005), at equal weight, the valves that are more spherical in cross section have a faster settling speed than flattened valves; at higher ratio of weight per area a valve settles faster regardless of its longitudinal profile. Using these basic assumptions, the taxa present in the studied sample have been analysed.

Both $P$. vailhanensis and S. havliceki have dorsibiconvex shells, so they are expected to behave similarly during transport. The ventral valves of both taxa are slightly convex or almost flat, so according to the premises of Simões et al. (2005), they are susceptible to suffer more transport rates than the more convex dorsal valves. Because the ratios of the ventral to dorsal valves $(\mathrm{vv} / \mathrm{dv})$ in Proclinorthis (0.85) and in Svobodaina (0.78) are close to one, the distance that they were transported from the initial accumulation area to the final accumulation area must have been short, if it occurred at all. The poor size selection of both Proclinorthis and Svobodaina (Fig. 8A-D) is also consistent with a short transport distance, although the Svobodaina valves could have suffered a slightly longer displacement. In the sample, medium and large sized Svobodaina dorsal valves are less common than the smaller ones. Because the Svobodaina dorsal valves are relatively planar during the early stages of growth and greater convexity is not developed until the adult stages, they could have undergone shape sorting. The adult dorsal valves, which are more convex, larger, and have higher settling velocities than juvenile valves, would have remained much closer to the initial accumulation area. In comparison, the convexity of Proclinorthis valves is fairly homogeneous during the whole ontogeny and so those shells did not undergo a significant shape sorting. To summarise, the total disarticulation of the studied shells indicates that the assemblage has been disturbed, although to a low degree, based on the wide size distribution and the lack of preferred orientation of the valves, as well as the ratio of ventral to dorsal valves, which approaches unity. According to Pickerill \& Brenchley (1979), this kind of poorly sorted and poorly oriented assemblages could be the result of storm activities, particularly in the near-shore and littoral environments, the transport and winnowing not being important enough to modify the original associations. Nevertheless, although this holds for the Svobodaina and Proclinorthis assemblage, that can be regarded as representative of an original community, some data points to a certain mixing with other faunal elements.

Hedstroemina undergoes important shape changes during ontogeny, their young ventral valves being fairly planar in contrast with the dorsally geniculate and strongly convex adult ventral valves. In the studied sample, the young Hedstroemina ventral valves are abundant, but only a few adult geniculate valves occur (see Fig. 8E). They appear to have undergone a strong shape sorting, with the hemispherical adult ventral valves having remained closer than the young valves to the initial accumulation area. The ratio of ventral to dorsal valves in Hedstroemina is very low $(\mathrm{vv} / \mathrm{dv}=0.17)$ which also suggests an important shape sorting. Although in the young stages of this genus the ventral and dorsal valves are almost flat, displaying almost no differences in depth, small differences in other features, such as the interarea height and attitude, or internal protuberances, could facilitate the shape sorting. According to Noble \& Logan (1981) this sorting does not necessarily imply a high degree of transport in high-energy environments, although it can be concluded that Hedstroemina shells underwent significantly more transport than those of Proclinorthis and Svobodaina.

\section{Functional morphology}

The conclusions of the taphonomic analysis suggesting a different origin for the valves of Proclinorthis and Svobodaina than the valves of Hedstroemina, are strengthened by a functional morphological analysis of these genera, assessing their different energetic adaptations. The very large and flabellate ventral diductor scars of Svobodaina havliceki and Proclinorthis vailhanensis reflect the strength required to keep the shell open under high-energy conditions, thus avoiding a sudden shell closure that could damage the mantle margins (Carls et al. 1993). This ability would allow them to thrive in the shallow marine shelf with shifting sand, inferred from the sedimentary evidence. If so, these brachiopods should have developed special pedicle adaptations for anchoring in the shifting sand substrates. Similar adaptations in similar environments are known from the 

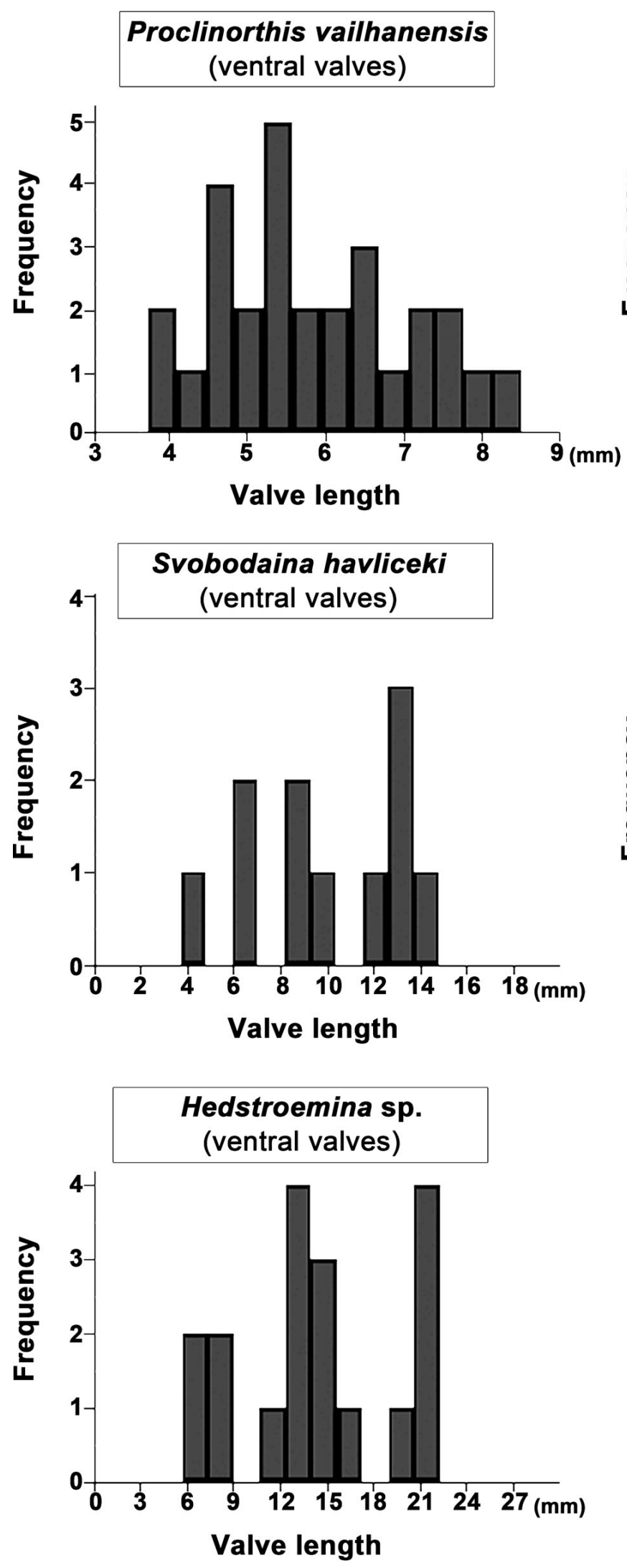
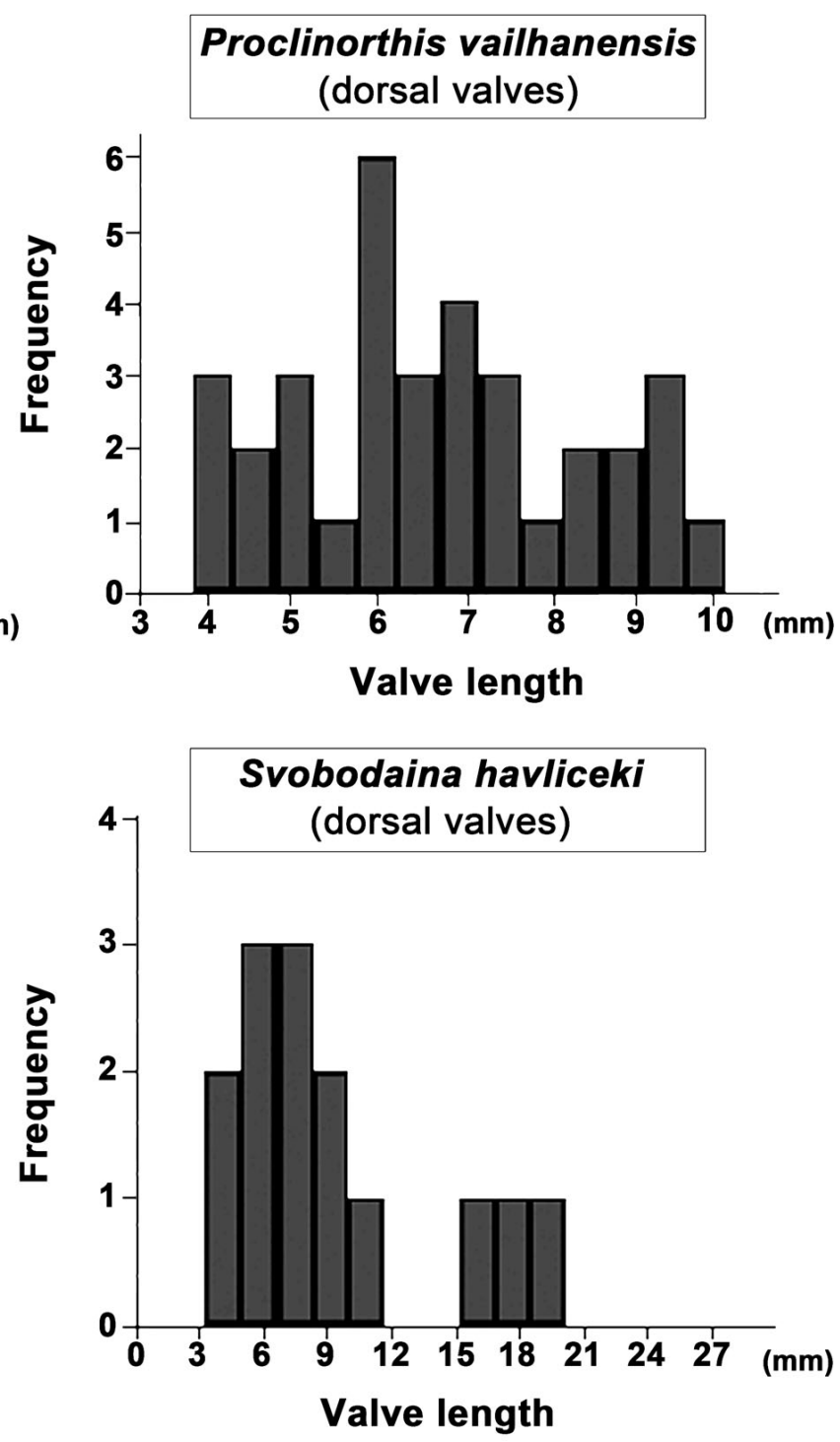

Figure 8. Histograms showing size-frequency distribution of ventral and dorsal valves of the commonest brachiopods in the sample. 
Australian recent brachiopod Parakinetica stewarti Richardson, 1987, that lives in shifting bryozoan sands in tidal environments. This species has a free pedicle, and its ratcheting action moves the organism upward, preventing it from burial when the input of sand increases, and downward when the sand substrate is shifted (Richardson 1997).

On the other hand, Hedstroemina sp. can be inferred as libero-sessile and semi-infaunal in the adult stages, due to its geniculate adult ventral valve with a closed pedicle opening. This life style would preclude its survival in the high-energy environments noted above for Proclinorthis and Svobodaina, and in agreement with our taphonomic conclusions suggesting a different initial accumulation area for these two taxa. The living environment of Hedstroemina sp. must have been more distal and deeper compared to that of Proclinorthis and Svobodaina, but always above the storm wave base. Longvillia mediterranea or Rafinesquina pomoides Havlíček, 1971 would have thrived in an environment similar to that inhabited by Hedstroemina sp. These two species, also frequent in the S. havliceki associations, have a similar shell shape and can be also interpreted as libero-sessile and recumbing during the adult stages.

\section{The Svobodaina havliceki Community}

The association of Svobodaina havliceki with quartzitic sandstone lithofacies is very frequent in Upper Ordovician outcrops throughout southwestern Europe. It is frequent to find in that lithofacies, besides $S$. havliceki, different species of the genera Aegiromena, Drabovia, Hedstroemina, Longvillia, Rafinesquina, Rostricellula, Tafilaltia and Triplesia. A list of genera that Proclinorthis gen. nov. can be now added to. Nevertheless, the associations are usually of very low diversity, restricted to three or four species accompanying Svobodaina. This recurrent brachiopod association from the cold-water shallow shelves bordering Gondwana, prior to the Boda event, has been referred to informally as the Svobodaina fauna (Leone et al. 1991). The brachiopod assemblage from the Glauzy Formation can clearly be included within this fauna. The lower than average diversity and the detected faunal mixing of parautochthonous and allochthonous taxa within the assemblage, do not allow its introduction as the typical representative of a formal palaeoecological unit. However, because the recurrent association of brachiopods characterised by the occurrence of $S$. havliceki is now well known from the Upper Ordovician of central Iberia (Villas 1995), the Iberian Chains (Villas 1985), the Pyrenees (Gil-Peña et al. 2004), Sardinia (Leone et al. 1991) and now the Montagne Noire, it seems appropriate to introduce formally a new community to include it. Following Pickerill \& Brenchley (1979), we understand a community as a spatially repeated and tempo- rally recurring group of organisms usually related to specific environmental parameters. Following the example of Hurst (1975), we are naming the community after its most abundant species. Although we agree with Pickerill \& Brenchley (1979) that this procedure can lead to a proliferation of community names, the generic designation is not adequate in this case. Svobodaina is known from a number of species ranging from the middle Sandbian (S. armoricana Babin \& Mélou, 1972) to the latest Katian (Svobodaina feisti Havlíček, 1981) from southwestern and central Europe to north Africa. Their species are highly variable in the size and shape of their ventral muscle field, often related to different degrees of turbulence, as discussed above. For instance, S. feisti is very abundant in the marlycalcareous facies overlying the Glauzy Formation of the Montagne Noire. It is found with taxa typical of the Nicolella Community (Havlíček 1981) that Pickerill \& Brenchley (1979) assigned to the Benthic Assemblage 3-4 of Boucot (1975); if so, S. feisti would be adapted to a deeper and less energetic environment than S. havliceki. Something similar occurs with Svobodaina ellipsoides (Barrande, 1848), a Bohemian species suggested to have thrived in the BA-5, that is, a much deeper and quieter environment than $S$. havliceki or S. feisti occupied. Even more, because Havlíček (1982) named a community after S. ellipsoides, to name a new community now employing only the generic designation could cause confusion.

Composition. - The only characteristic brachiopod species of this community is Svobodaina havliceki, which is usually accompanied by other taxa that vary geographically and probably also stratigraphically, such as Proclinorthis, Tafilaltia and Drabovia. Proclinorthis is the dominant taxon in the Montagne Noire association, its only known occurrence; Tafilaltia is a secondary member of the association from central Iberia (Villas 1995), and Drabovia is a minority genus in the Iberian Chains association (Villas 1985). It is frequent to find within these associations disarticulated shells in variable proportions of large, strongly inequivalve strophomenoids such as Hedstroemina (Montagne Noire, Pyrenees and central Iberia), Longvillia (Montagne Noire and Pyrenees) and Rafinesquina (Iberian Chains, Pyrenees and Sardinia). Nevertheless, as happens with Hedstroemina in the Montagne Noire, these strophomenoid valves always display a very low ratio of ventral to dorsal valves, reflecting substantial transport, possibly from adjacent communities farther offshore and in deeper water. The rhynchonellid Rostricellula occurs in highly variable proportions in several of the recorded associations that can be referred to as the $S$. havliceki Community. It can fluctuate from total absence, as in the Montagne Noire or central Iberia (Villas 1995), to a few dispersed valves, as in the Iberian Chains (Villas 1985) or Sardinia (Leone et al. 1991), to enormous accumulations of disarticulated valves 


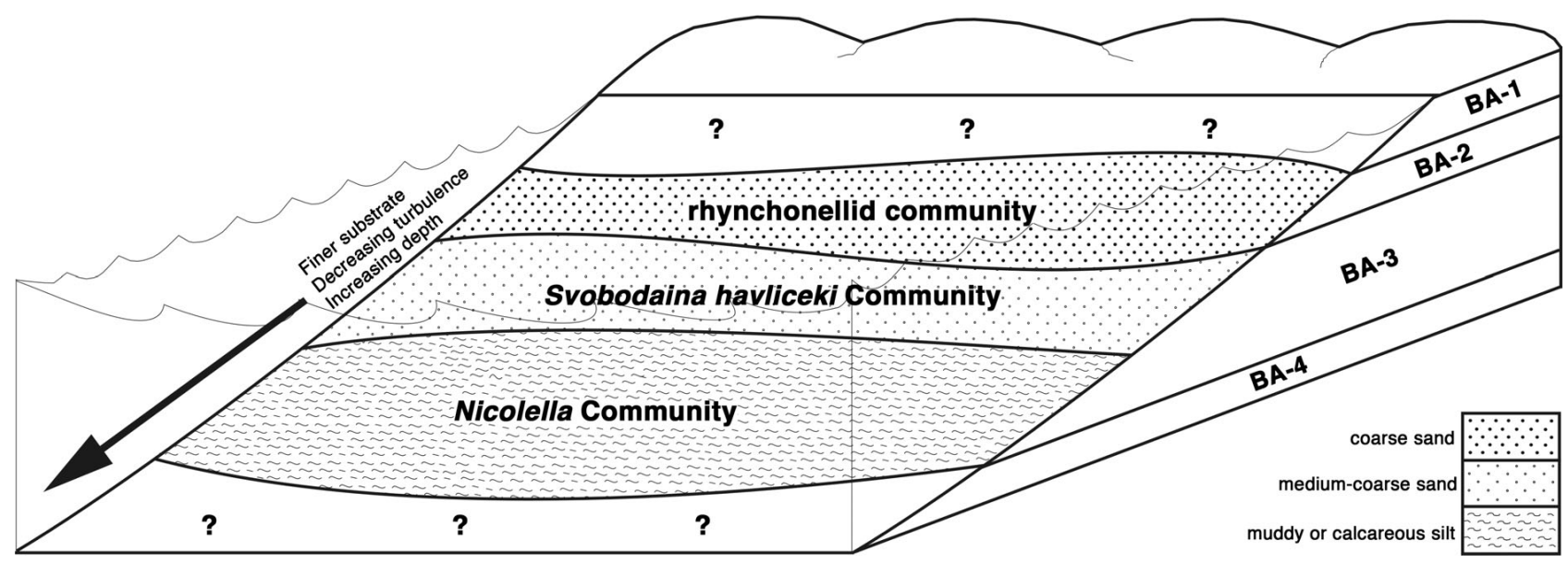

Figure 9. Schematic illustration of the mid Katian North-Gondwanan communities and their relationship with the environmental parameters.

on bedding planes, as in the Pyrenees. Rostricellula can be interpreted as a characteristic species of a neighbouring community, in this case from more near-shore and shallower waters, to which the rhynchonellids are known to be well adapted. Other extremely minor genera within the studied associations, such Triplesia, in the Glauzy Formation assemblage, can be interpreted as ubiquitous species.

Substrate and environment. - Shifting, medium grained, sand substrates in high-energy environments of the shore face.

Comparison with other Upper Ordovician communities. The Bohemian Ordovician rocks are the only remnant of a basin of the Mediterranean margin of Gondwana where the brachiopod communities have been defined (Havlíček 1982). However, because the most proximal environments are not preserved in the Bohemian Upper Ordovician sedimentary succession (Havlíček \& Fatka 1992) none of the brachiopod communities proposed there are comparable with the new community. The high latitude Mediterranean margin of Gondwana suffered an important faunal isolation during the Ordovician, prior to the late Katian transgression that accompanied the Boda event. That explains the difficulty in finding similar taxonomic compositions in benthic associations on both sides of the Rheic Ocean, or from very different palaeolatitudes or distant palaeocontinents, even though they could be adapted to similar environments. In the Upper Ordovician of north Wales, representing the Avalonian margins, Pickerill \& Brenchley (1979) described the Dinorthis Community, specifically the Dinorthis Sub-community, as being adapted to a similar environment to that inferred for the S. havliceki Community. According to these authors, the Dinorthis Sub-community was particularly associated with medium to coarse sand substrates, in high-energy, non-turbid, well-oxygenated sub-littoral environments of water depths of less than approximately $10 \mathrm{~m}$. The sub-community is of low diversity, with only Dinorthis and Heterorthis as the characteristic genera, and Reuschella and Macrocoelia as common intergrading elements with adjacent communities. In spite of the faunal isolation between our region and Avalonia during most of the time range of the S. havliceki Community, there are some taxonomic affinities with the Dinorthis Sub-community. The Avalonian Heterorthis, also with a large, flabellate ventral muscle field, can be considered the alter ego of the also heterorthid S. havliceki in the Mediterranean community.

Adjacent communities and benthic assemblages. - The Upper Ordovician sedimentary record displays little lateral facies changes within the known isolated remnants of the Mediterranean Gondwana margin. Physical transects through different depositional environments have been described very rarely, as with the upper Katian Cystoid Limestone in the Iberian Chains (Vennin et al. 1998). In a few other cases, transect reconstructions have been made from the study of vertical facies changes, for example in the also upper Katian Portixeddu Formation in Sardinia (Botquelen et al. 2006). However, no such physical transects have been described for the Katian siliciclastic units where the S. havliceki Community usually occurs. In spite of this, from analysis of the faunal mixing of the characteristic integrants of the community with those reworked and transported elements, it is possible to infer their adjacent communities. One of those reworked elements in the Montagne Noire and the Pyrenees associations is Longvillia mediterranea, a species characteristic of the Nicolella Community, well known from the overlying carbonate unit (Havlíček 1981). The source of the transported valves of Hedstroemina found in the Montagne Noire, but also common as reworked elements within the S. havliceki Community in other Mediterranean localities (Cava Fm., Pyrenees; Porto de Santa Anna Fm., Portugal; "Bancos Mixtos", central 
Iberia) is not so clear. They should come from a more distal environment, as deduced above from its life style, but its only record within the Nicolella Community is in the Iberian Chains (Villas 1985). Its origin could be in a different association, not recorded up to now, of similar environmental restrictions to the Nicolella Community. Other reworked elements from the Nicolella Community are Portranella exornata (= Paucicrura ichnussae and $P$. cf. fascicula), Eoplectodonta (Kozlowskites) ichnussae, Aegiromena meneghiniana and Iberomena sardoa, occurring besides $S$. havliceki in the uppermost "Bancos Mixtos" of central Iberia (Villas 1995). I. sardoa also occurs within a S. havliceki Community in the Sardinian Portixeddu Formation (Leone et al. 1991).

The replacement of the $S$. havliceki Community by the Nicolella Community during the late Katian, throughout most of the Mediterranean margin of Gondwana, in addition to the intermixing of species of both communities, strongly points to their physical proximity. Botquelen et al. (2006) identified four different brachiopod associations within the Nicolella Community in Sardinia, in proximal to distal upper offshore sedimentary facies. It is noteworthy that of those four associations, the most proximal is dominated by L. mediterranea, of which some transported valves are occasionally found with the characteristic species of the $S$. havliceki Community. It can be concluded that the Nicolella Community was adjacent to the S. havliceki Community, on its seaward side, during the first pulses of the Boda event.

Pickerill \& Brenchley (1979) assigned the Nicolella Community to the BA-3 or 4, more probably to the BA-3. We agree with this preferred assignation, considering the known occurrence of the algal genera Ischadites and Cyclocrinites within the community in the Upper Ordovician of Sardinia (Hammann \& Serpagli 2003). They could not have survived in a BA-4, typically placed below the lower limit for active photosynthesis (Boucot 1975).

With respect to its landward boundary, it can be suggested a rhynchonellid-dominated community occurs there, considering the occasional finding of Rostricellula within the associations referred to as the S. havliceki Community. Such a community would fit within the BA-2, characterised by single-taxon associations, very often of rhynchonellids (Boucot 1975).

Considering the assignation to benthic assemblages of its adjacent communities, the $S$. havliceki Community can be included within the BA-3, concretely in its most proximal part, related with the shore face, above the fair-weather wave base. The BA-2 can be ruled out, because the community does not fit with the typical features of single-taxon communities or higher-diversity communities with relatively larger specimens (Boucot 1975). In the same way, the Dinorthis Community, compared above with the S. havliceki Community, can be also discarded from the
BA-2, where Pickerill \& Brenchley (1979) placed it. They described the environment where the community thrived as shallow sublittoral, probably less than approximately $10 \mathrm{~m}$ deep (Pickerill \& Brenchley 1979, p. 246). Because Boucot (1975) placed the boundary between the BA-2 and the BA-3 at the low tide sea level, the sublittoral environment described for the Dinorthis Community is a better fit with the BA-3, in a non-macrotidal regime in which the maximum low tide did not reach $10 \mathrm{~m}$ deep.

Our proposal for the distribution of the Mediterranean benthic communities and their relationship with the environmental parameters during the mid-Katian is presented in the Fig. 9.

Stratigraphic distribution. - The nominal species of the community is very abundant in the fossiliferous horizon 3 (FH 3) of the Jabalón River Section in central Iberia (Villas 1995). This author suggests correlating those horizons with the Marshbrookian to Pusghillian British stages, that is, from the Ka1 to the Ka2 stage slices of the Katian Global stage. Although the community was apparently fully replaced throughout the Mediterranean Gondwana margin by the Nicolella Community during the late Katian, it could have survived for some time in more proximal sedimentary environments of the region, unrecorded until now.

\section{Conclusions}

The brachiopod association recorded in the quartzitic sandstones underlying the very fossiliferous upper Katian carbonates of the Montagne Noire allows envisaging the last moments of the endemic benthic fauna of the Ordovician high latitude margin of Gondwana. Its low diversity associations were mostly adapted to shallow siliciclastic shelves, in high-energy environments, bordering Gondwana from present-day Turkey to present-day Iberia. By the mid Katian the Mediterranean margin of Gondwana gives the first signals of losing its isolation with respect to the low latitude palaeocontinents. The settling of some brachiopods of the Nicolella Community, typical until then of the Avalonian margins, is recorded on the upper offshore of the Mediterranean platforms (most distal part of the BA-3). They are bounded coastward by the Svobodaina havliceki Community (most proximal part of the BA-3), widespread on those platforms during the early Katian, and characterised by genera of the Mediterranean endemic families Heterorthidae and Draboviidae. With the sea level rise, accompanying the global warming Boda event, the siliciclastic substrates were widely replaced by carbonate sediments on the Mediterranean platforms. Bryozoan and pelmatozoan meadows developed on the new muddy or calcareous silty substrates, and the brachiopods of the high diversity Nico- 
lella Community thrived, displacing the S. havliceki Community. They were mostly immigrants from low latitude palaeocontinents, although some representatives of the formerly successful Mediterranean families such as Svobodaina feisti or rare draboviids and aegiromeninins were also included. The carbonate sedimentation did not extend to the innermost North African shelves, where the heterorthids and draboviids still dominated during the upper Katian (Villas et al. 2006), but where the members of the S. havliceki Community have not been recorded.

\section{Acknowledgements}

We thank to Petr Štorch for his useful comments and to the reviewers Michal Mergl (University of West Bohemia) and Rong Jia-Yu (Nanjing Institute of Geology and Palaeontology) for their helpful revisions that have contributed to improving the manuscript. This paper is a contribution to the Spanish Ministry of Science and Innovation project CGL 2009-09583, and to the IGCP 591 project: The Early to Middle Paleozoic Revolution.

\section{References}

Álvaro, J.J. \& Vizcaïno, D. 2001. Evolutionary trends in the ornamentation of Cambrian Solenopleuropsinae Trilobites. Palaeontology 44, 131-141. DOI 10.1111/1475-4983.00173

Babin, C., Feist, R., Melou, M. \& Paris, F. 1988. La Limite Ordovicien-Silurien en France, 73-79. In Cocks, L.R.M. \& RicKARDS, R.B. (eds) A Global Analysis of the Ordovician-Silurian Boundary. Bulletin of the British Museum (Natural History) Geology 43.

BAnCROFT, B.B. 1929. Some new genera and species of the Strophomenacea from the Upper Ordovician of Shropshire. Memoirs of the Manchester Literary and Philosophical Society 73, 33-65.

BARRANDE, J. 1848. Über die Brachiopoden der silurischen Schisten von Böhmen. Naturwissenschaftliche Abhandlungen 2, 155-256.

BERARD, P. 1986. Trilobites de l'Ordovicien Inférieur des Monts de Cabrières (Montagne Noire - France). Mémoires du Centre d'Etudes et de Recherches Géologiques et Hydrologiques. Université des Sciences et Techniques (Montpellier II) 24. 220 pp. CERGA, Montpellier.

BERGERON, J. 1889. Étude géologique du Massif ancien situé au S. du Plateau central. Thèse. Annales des Sciences Géologiques 22, 1-632.

Bergeron, J. 1890. Sur une nouvelle forme de Trilobite de la famille des Calymenidae (genre Calymenella). Bulletin de la Société géologique de France (3ème série) 18, 365-371.

Bergström, S.M., Chen, X., Gutiérrez-Marco, J.C. \& Dronov, A. 2009. The new chronostratigraphic classification of the Ordovician System and its relations to major regional series and stages and to $\delta^{13} \mathrm{C}$ chemostratigraphy. Lethaia 42, 97-107. DOI 10.1111/j.1502-3931.2008.00136.x
Botquelen, A., Gourvennec, R., Loi, A., Pillola, G.L. \& Leone, F. 2006. Replacements of benthic associations in a sequence stratigraphic framework, examples from Upper Ordovician of Sardinia and Lower Devonian of the Massif Armoricain. Palaeogeography, Palaeoclimatology, Palaeoecology 239, 286-310. DOI 10.1016/j.palaeo.2006.01.016

Boucot, A.J. 1975. Evolution and extinction rate controls. 427 pp. Elsevier, New York.

Boucot, A.J., Johnson, J.G. \& Walmsley, V.G. 1965. Revision of the Rhipidomellidae (Brachiopoda) and the affinities of Mendacella and Dalejina. Journal of Paleontology 39, 331-340.

Boucot, A.J., Rong, J.-Y., Chen, X. \& Scotese, C.R. 2003. Pre-Hirnantian Ashgill climatically warm event in the Mediterranean region. Lethaia 36, 119-132. DOI 10.1080/00241160310001245

Buttler, C. \& Massa, D. 1996. Late Ordovician bryozoans from carbonate buildups, Tripolitania, Libya, 63-68. In Gordon, D.P., Smith, A.M. \& Grant-Mackie, J.A. (eds) Bryozoans in space and time. Proceedings of the $10^{\text {th }}$ International Bryozoology conference, Wellington, New Zealand, 1995. National Institute of Water \& Atmospheric Research Ltd, Wellington.

Carls, P., Meyn, H. \& Vespermann, J. 1993. Lebensraum, Entstehung und Nachfahren von Howellella (Iberohowellella) holmanni n. sg., n. sp. (Spiriferacea; Lochkovium, UnterDevon). Senckenbergiana lethaea 73, 227-267.

Centène, A. \& Sentou, G. 1975. Graptolites et conodontes du Silurien des massifs du Midi Méditerranéen. Thèse de spécialité, Université des Sciences et Techniques du Languedoc, Montpellier, France.

Cocks, L.R.M. 2010. Caradoc Strophomenoid and Plectambonitoid brachiopods from Wales and the Welsh borderland. Palaeontology 53, 1155-1200.

Cocks, L.R.M. \& Rong, J-Y. 2000. Strophomenida, 216-348. In KAESLER, R.L (ed.) Treatise on Invertebrate Paleontology. $H$ 2. Linguliformea, Craniiformea, and Rhynchonelliformea (part), revised. Geological Society of America \& University of Kansas Press, Boulder \& Lawrence. DOI 10.1111/j.1475-4983.2010.00984.x

DAVIDSON, T. 1848. Mémoire sur les brachiopodes du Système Silurien supérieur de l'Angleterre. Bulletin de la Société géologique de France, série 2, 5, 309-338, 370-374.

Dreyfuss, M. 1948. Contribution a l'étude géologique et paléontologique de l'Ordovicien Supérieur de la Montagne Noire. Mémories de la Société Géologique de France 58, 1-63.

Elaouad-Debbaj, Z. 1978. Acritarches de l'Ordovicien Supérieur du Synclinal de Buçaco (Portugal). Bulletin de la Societé Géologique et Minéralogique de Bretagne 10, $1-101$.

Emmons, E. 1842. Geology of New York, Part II. Comprising the survey of the second geological district. Natural History of New York. 437 pp. New York State Museum, New York.

Engel, W., Feist, R. \& Franke, W. 1979. Carte Géologique du flysch carbonifère entre le Mont Peyroux et Cabrières. Montagne Noire SE, Hérault (France) 1:25000. In FEIST, R. (ed.) 
GRECO No. 7 du C.N.R.S. Laboratoire de Géologie Historique. U.S.T.L., Montpellier.

Feist, R. \& Echtler, H. 1994. The Massif Central: external zones, 291-297. In KeppIE, J. (ed.) Pre-Mesozoic geology in France and related areas. Springer-Verlag, Berlin \& Heidelberg.

ForTEY, R.A. \& COCKS, L.R.M. 2005. Late Ordovician global warming - The Boda event. Geological Society of America Bulletin 33, 405-408.

FreCh, F. 1887. Die Paläozoischen bildungen von Cabrières (Languedoc). Zeitschrift der Deutschen Geologischen Gessellschaft 39, 360-488.

Gil-Peña, I., Barnolas, A., Villas, E. \& Sanz-López, J. 2004. El Ordovícico Superior de la Zona Axial, 247-249. In VerA, J.A. (ed.) Geología de España. SGE-IGME, Madrid.

Gonord, H., Ragot, J.P. \& SAUgy, L. 1964. Observations lithostratigraphiques nouvelles sur la série de base (Ordovicien inférieur) des nappes de Cabrières, région de Gabian-Glauzy (Montagne-Noire, Hérault). Bulletin de la Société Géologique de France 7, 419-427.

Graff, M. 1874. Notice sur les Terrains Paléozoïques du Département de l'Hérault. $68 \mathrm{pp}$. Société Scientifique et Industrielle, Lyon.

GRAY, J.E. 1840. Synopsis of the contents of the British Museum. $42^{\text {th }}$ edition. 370 pp. British Museum, London.

HAFEnRIChTER, M. 1979. Paläontologisch-Ökologische un Lithofazielle Untersuchungen des "Ashgill-Kalkes" (Jungordovizium in Spanien). Arbeiten aus dem Paläontologischen Institut Würzburg 3,1-139.

HALL, J. 1859. Containing descriptions and figures of the organic remains of the Lower Helderberg Group and the Oriskany Sandstone. Report of the Regents of the University for 1856, 3. 532 pp. Albany.

Hallman, D.P., Jonathan, D.M. \& Flessa, K.W. 1996. Experimental taphonomy: the effect of shell size and shape on transport within the intertidal zone. Sixth North American Paleontological Convention, The Paleontological Society Special Publication 8.

Hammann, W. \& Leone, F. 2007. Trilobites of the post-Sardic (Upper Ordovician) sequence of southern Sardinia. Part II. Beringeria 38, 3-138.

Hammann, W. \& Serpagli, E. 2003. The algal genera Ischadites Murchison, 1839 and Cyclocrinites Eichwald, 1840 from the Upper Ordovician Portixeddu Formation of SW Sardinia. Bollettino della Società Paleontologica Italiana 42, 1-29.

Harper, C.W., JR., Boucot, A.J. \& Walmsley, V.G. 1969. The rhipidomellid brachiopod subfamilies Heterorthinae and Platyorthinae (new). Journal of Paleontology 43, 74-92.

HavlíčEK, V. 1951. The Ordovician brachiopoda from Bohemia. Rozpravy Ústředního ústavu geologického 12, 1-135.

HAVLÍ̌̌EK, V. 1970. Heterorthidae (Brachiopoda) in the Mediterranean Province. Sborník geologických věd, Paleontologie 12, 7-39.

HAVLíčEK, V. 1977. Brachiopods of the order Orthida in Czechoslovakia. Rozpravy Ústředního ústavu geologického 44, $1-327$.
HavlíčEK, V. 1981. Upper Ordovician brachiopods from the Montagne Noire. Paleontographica, Abteilung A 176, 1-34.

Havlí̌̌eK, V. 1982. Ordovician of Bohemia: Development of the Prague Basin and its benthic communities. Sborník geologických věd, Geologie 37, 103-136.

Havlí̌̌ek, V., KŘižz, J. \& Serpagli, E. 1987. Upper Ordovician brachiopod assemblages of the Carnic Alps, Middle Carinthia and Sardinia. Bollettino della Società Paleontologica Italiana $25,277-311$

Havlíček, V. \& FatKa, O. 1992. Ordovician of the Prague Basin (Barrandian area, Czechoslovakia), 461-472. In WeBBIE, B.D. \& LAURIE, J.R. (eds) Global Perspectives on Ordovician Geology. Balkerna, Rotterdam.

Hedberg, H. (ed.) 1976. International Stratigraphic Guide. 200 pp. I.S.S.C. Wiley \& Sons Ltd, New York.

Helbing, H. \& Tiepolo, M. 2005. Age determination of Ordovician magmatism in NE Sardinia and its bearing on Variscan basement evolution. Journal of the Geological Society of London 162, 689-700. DOI 10.1144/0016-764904-103

Heritsch, F. 1929. Faunen aus dem Silur der Ostalpen. Abhandlungen der Geologischen Bundesanstalt 23, 1-183.

HuRsT, J.M. 1975. Wenlock carbonate, level bottom, brachiopod-dominated communities from Wales and the Welsh Borderland. Palaeogeography, Palaeoclimatology, Palaeoecology 11, 227-255. DOI 10.1016/0031-0182(75)90024-3

HuRst, J.M. 1979. The stratigraphy and brachiopods of the upper part of the type Caradoc of south Salop. Bulletin of the British Museum (Natural History), Geology 32, 183-304.

InTERnational Subcommission on Stratigraphic Classification 1994. Unconformity-bounded stratigraphic units. Geological Society of America Bulletin 98, 232-237.

INTERNATIONAL SUBCOMMISSION ON STRATIGRAPHIC ClassifiCATION 1999. International Stratigraphic Guide. An abridged version. Episodes 22, 255-271.

JiMÉNEZ-SÁNCHEZ, A. \& Villas, E. 2010. The bryozoan dispersion into the Mediterranean margin of Gondwana during the pre-glacial Late Ordovician. Palaeogeography, Palaeoclimatology, Palaeoecology 294, 220-231.

DOI 10.1016/j.palaeo.2009.11.027

JoHnson, R.G. 1972. Conceptual models of benthic marine communities, 148-159. In Schopf, T.J.M. (ed.) Models in paleobiology. Freeman-Cooper, San Francisco.

KING, W. 1846. Remarks on certain genera belonging to the class Palliobranchiata. Annals and Magazine of Natural History 18, 26-42. DOI 10.1080/037454809494387

Koenen, A. von 1886. Ueber neue cystideen aus den Caradocschichten der gegend von Montpellier. Neues Jahrbuch für Mineralogie 2, 246-254.

Leone, F., Hammann, W., Serpagli, E. \& Villas, E. 1991. Lithostratigraphic units and biostratigraphy of the post-sardic Ordovician sequence in south-west Sadinia. Bolletino della Società Paleontologica Italiana 30, 201-235.

Melou, M. 1987. Découverte de Hirnantia sagittifera (M'Coy 1851) Orthida Brachiopoda dans l'Ordovicien supérieur (Ashgillien) de l'extrémité occidentale du Massif Armoricain. Geobios 20, 679-686. DOI 10.1016/S0016-6995(87)80022-0 
Noble, J.P.A. \& LogAn, A. 1981. Size-frequency distributions and taphonomy of brachiopods: a recent model. Palaeogeography, Palaeoclimatology, Palaeoecology 36, 87-105. DOI 10.1016/0031-0182(81)90051-1

North American Stratigraphic Commission 1983. North American stratigraphic code. The American Association of Petroleum Geologists Bulletin 67, 841-875.

Nysaether, E., Torsvik, T.H., Feist, R., Walder-Haug, H.J. \& EIDE, E.A. 2002. Ordovician palaeogeography with new palaeomagnetic data from the Montagne Noire (Southern France). Earth and Planetary Science Letters 203, 329-341. DOI 10.1016/S0012-821X(02)00847-6

OrbignY, A. D' 1847. Considérations zoologiques et géologiques sur les Brachiopodes ou Palliobranches. Comptes Rendus Hebdomadaires des Séances de l'Académie des Sciences 25, 193-195, 266-269.

Owen, A.W. \& Harper, D.A.T. 1982. The Middle Ordovician of the Oslo Region, Norway 31. The upper Caradoc trilobites and brachiopods from Vestbraten, Ringerike. Norsk Geologisk Tidsskrift 62, 95-120.

PARIS, F. 1979. Les chitinozoaires de la Formation de Louredo, Ordovicien Supérieur du synclinal de Buçaco (Portugal). Palaeontographica, Abteilung A 164, 24-51.

Paris, F. 1981. Les Chitinozoaires dans le Paléozoïque du SudOuest de l'Europe (Cadre géologique - Etude systématique Biostratigraphie). Mémoires de la Société géologique et minéralogique de Bretagne 26, 1-412.

Pickerill, R.K. \& Brenchley, P.J. 1979. Caradoc marine communities of the south Berwyn Hills, North Wales. Palaeontology 22, 229-264.

Popov, L.E., Cocks, L.R.M. \& NiKITIN, I.F. 2002. Upper Ordovician brachiopods from the Anderken Formation, Kazakhstan: their ecology and systematics. Bulletin of the British Museum (Natural History), Geology 58, 13-79.

RichARDSON, J.R. 1997. Ecology of articulated brachiopods, 441-460. In KAESLER, R.L (ed.) Treatise on Invertebrate Paleontology, Part H, Brachiopoda, Revised 1. Geological Society of America \& University of Kansas, Lawrence.

RõõmusOKs, A. 1993. Some brachiopod genera of the subfamily Strophomeninae from the Ordovician of Estonia. Proceedings of the Estonian Academy of Sciences, Geology 42, $110-117$.

Rouville, P.G. de 1888. Sur un horizon à Trinucleus du Glauzy (Hérault). Ibid 107, 841-842.

Rouville, P.G. De \& Delage, A. 1892. Géologie de la région de Cabrières (Hérault), Carte géologique 1/40000. Imprimerie Firmin \& Montane, Montpellier.

Schönlaub, H.P. 1998. Review of the Paleozoic paleogeography of the southern Alps - The perspective from the Austrian side. Giornale di Geologia 60, Spec. Issue, ECOS VII Southern Alps Field Trip Guidebook, 59-68.

SchÖNLAUB, H.P. \& Histon, K. 2000. The Palaeozoic evolution of the southern Alps. Mitteilungen der Österreichischen geologischen Gesellschaft 92, 13-34.

SCHUChert, C. 1893. Classification of the Brachiopoda. American Geologist 11, 141-167.
Schuchert, C. 1913. Brachiopoda, 335-420. In Zittel, K.A. (ed.) Text-book of Paleontology, Volume 1, $2^{\text {nd }}$ edition. Macmillan and Company, London.

DOI 10.2475/ajs.s5-22.129.241

Schuchert, C. \& Cooper, G.A. 1931. Synopsis of the Brachiopod genera of the suborders Orthoidea and Pentameroidea, with notes on the Telotremata. American Journal of Science 22, 241-251.

Simões, M.G. \& KowalewsKi, M. 2003. Modern accumulations of brachiopod shells in unconsolidated surficial beach deposits, northern coast of São Paulo State, Brazil: Taphonomic implications for the genesis of skeletal concentration, 220-223. In $3^{\text {rd }}$ Latin American Congress of Sedimentology, Belém, Brazil, Abstracts.

Simões, M.G., Rodrigues, S.C., Leme, J.M. \& Bissaro, M.C., JR. 2005. The settling behaviour of brachiopod shells: stratigraphical and taphonomical implications to shell bed formation and paleoecology. Revista Brasileira de Geociência 35, 383-391.

Sowerby, J. DE C. 1839. Fossil shells of the lower Ludlow age. In Murchinson, R.I. The Silurian System, founded on geological researches in the counties of Salop, Hereford, Radnor, Montgomery, Caermarthen, Brecon, Pembroke, Monmouth, Gloucester, Worcester, and Stafford; with descriptions of the coalfields and overlying formations. John Murray, London.

S̆TORCH, P. \& FEIST, R. 2008. Lowermost Silurian graptolites of Montagne Noire, France. Journal of Paleontology 82, 938-956. DOI 10.1666/07-004.1

THORAL, M. 1946. Cycles géologiques et formations nodulifêres de la Montagne Noire. Nouvelles Archives du Muséum d'Histoire Naturelle de Lyon 1, 1-103.

VAI, G.D. 1971. Ordovicien des Alpes carniques. Colloques Ordovicien-Silurien, Brest 1971. Mémoires du Bureau de Recherches géologiques et minères 73, 437-450.

Vennin, E., Álvaro, J.J. \& Villas, E. 1998. High-latitude pelmatozoan-bryozoan mud-mounds from the late Ordovician northern Gondwana platform. Geological Journal 3, 121-140. DOI 10.1002/(SICI)1099-1034(1998040)33:2<121::AID-GJ 780>3.0.CO;2-D

VILLAS, E. 1983. Las formaciones del Ordovícico medio y superior de las Cadenas Ibéricas y su fauna de braquiópodos. Estudios Geológicos 39, 359-377.

VILLAS, E. 1985. Braquiópodos del Ordovícico medio y superior de las Cadenas Ibéricas Orientales. Memorias del Museo Paleontológico de la Universidad de Zaragoza 1, 1-153.

ViLLAs, E. 1995. Caradoc through early Ashgill brachiopods from the Central-Iberian Zone (Central Spain). Geobios 28, 49-84. DOI 10.1016/S0016-6995(95)80204-5

Villas, E., Harper, D.A.T., Melou, M. \& Vizcaïno, D. 1995. Stratigraphical significance of the Svobodaina species (Brachiopoda, Heterorthidae) range in the Upper Ordovican of South-Western Europe, 97-98. In CoOper, J.D., Droser, M.L. \& FinNEY, S.C. (eds) Ordovician Odyssey. Short papers for the seventh International Symposium on the Ordovician System, Las Vegas 1995. 
Villas, E., Vennin, E., Álvaro, J.J., Hammann, W., Herrera, Z.A. \& Piovano, E.L. 2002. The late Ordovician carbonate sedimentation as a major triggering factor of the Hirnantian glaciation. Bulletin de la Societé géologique de France 173, 569-578. DOI 10.2113/173.6.569

Vinassa de Regny, P. 1910. Fossili Ordoviciani del Nucleo Centrale Carnico. Atti della Accademia Gioenia di Scienze Naturali in Catania 3, 1-48.

Vinassa de Regny, P. 1927. Fossili Ordoviciani sardi. Memorie della reale Accademia dei Lincei 2, 437-496.
Williams, A. 1963. The Caradocian brachiopod faunas of the Bala District, Merionethshire. Bulletin of the British Museum (Natural History), Geology 8, 327-471.

WiLliams, A. 1974. Ordovician brachiopoda from the Shelve district, Shropshire. Bulletin of the British Museum (Natural History), Geology, supplement II, 1-163.

Williams, A. \& HARPER, D.A.T. 2000. Orthida, H714-H731. In KAESLER, R.L (ed.) Treatise on Invertebrate Paleontology, Part H, Brachiopoda; Revised Volume 3. Geological Society of America \& University of Kansas Press, Boulder. 